\title{
"As estrelas eram terrenas": antropologia do clima, da iconografia e das constelações Ticuna $^{1}$
}

\author{
Priscila Faulhaber \\ Pesquisadora titular - Museu Goeldi
}

\begin{abstract}
RESUMO: A antropologia do clima abrange o estudo da significação dos fenômenos astronômicos e atmosféricos nos mitos e ritos indígenas, bem como a importância das representações sobre tais fenômenos para as práticas sociais de povos indígenas como o Ticuna. A identificação dos corpos celestes, presentes na iconografia dos artefatos utilizados na festa de puberdade Ticuna, remete a aspectos da mitologia e da cosmovisão deste povo, expressos em cantos e relatos rituais, traduzidos em termos das expectativas em face das relaçóes entre o movimento das estrelas no céu ao longo do ano e a influência da sazonalidade das chuvas e da estiagem nas atividades de sobrevivência. Tal identificação de agrupamentos de corpos celestes visualizados pelos Ticuna permite correlações com as constelaçôes reconhecidas convencionalmente.
\end{abstract}

PALAVRAS-CHAVE: antropologia do clima, sazonalidade, movimentos das estrelas, identificação do céu.

\section{Introdução}

As expectativas dos Ticuna em face das mudanças climáticas estão impressas na iconografia de narrativas gráficas inscritas em indumentárias de máscaras ou panos ou "rodas" rituais, coletados pelo etnólogo alemão 
Priscila Faulhaber. “As estrelas eram terrenas”...

Curt Nimuendaju em 1941 e 1942, abrigados no acervo etnológico da Coordenação de Ciências Humanas do Museu Paraense Emílio Goeldi. Essas narrativas gráficas tratam, principalmente, de mitos, práticas e eventos relacionados com o cotidiano dos membros das comunidades Ticuna. O exame da literatura especializada, com base em observações etnográficas, permite correlacioná-las com mitos e relatos orais. Em tais narrativas, registra-se que os Ticuna descendem do povo Magüta, povo este pescado nas cabeceiras do Eware ${ }^{2}$, um igarapé localizado, segundo tais referências, na montante do igarapé homônimo, que é um afluente do igarapé São Jerônimo, o qual desemboca na margem esquerda do rio Solimões.

Essas narrativas referem-se, igualmente, às atividades na unidade doméstica e no seu grupo de pertencimento: em suas casas, no trabalho sobre a terra, na pesca, na coleta, na caça e nas relações com as forças que regem o movimento dos rios e a vida na floresta. Essas atividades requerem o recurso à memória para o reconhecimento, por exemplo, dos caminhos que levam aos lugares de coleta e de fartura da caça. Recorrem a técnicas de observação dos astros no céu e de fenômenos meteorológicos, associados a pistas deixadas por animais que povoam o céu, e cujo movimento é comparado com um relógio para as atividades de sobrevivência, como a caça e a pesca. A identificação de estrelas ou constelações no céu é comparada, em alguns depoimentos, à leitura de uma forma de escrita. O manejo de tais técnicas remonta ao conhecimento acumulado e transmitido de geração a geração por meio dessas narrativas orais, bem como das registradas mediante diferentes formas de expressão gráfica. De acordo com o que se depreende dos depoimentos Ticuna, tais narrativas, referentes ao tempo mítico de existência do povo Magüta, não datado cronologicamente, estão registradas na memória, afirmando-se que as pessoas se lembram do que ocorria "naquele tempo", representado miticamente e que coexiste com o tempo das atividades regulares. 
Dentro de uma discussão sobre a "antropologia do clima" e a "religiosidade climática", examina-se o imaginário de tais narrativas a partir do estabelecimento de correlações entre aspectos da cosmovisão Ticuna, impressos na iconografia dos artefatos rituais, e as interpretaçôes, por representantes deste povo, da sazonalidade das chuvas e da estiagem. Trata-se, ao fim do trabalho, de estabelecer correlações entre representações Ticuna sobre agrupamentos de estrelas e estrelas visíveis em constelações convencionadas pela astronomia ocidental, no que diz respeito a uma reflexão do significado de tais agrupamentos para a interpretação da sazonalidade.

\section{Delimitando a perspectiva de análise e os procedimentos de pesquisa}

O calendário de diferentes povos se rege por fenômenos como o aparecimento e desaparecimento no céu de astros ou conjuntos de estrelas. Olhando os árcos no céu, a imaginação cria figuras que compõem as histórias contadas associadas a determinados eventos atmosféricos ou astronômicos. Tais narrativas são potencializadas por especialistas, que delas se valem para dar sentido aos ritos. $\mathrm{O}$ aparecimento, no início da noite, das Plêiades no horizonte Leste em novembro, que representa para os Barasana o tempo da coleta de ingá, é relacionado ao uso ritual das fibras de determinadas palmeiras e assume um significado especial no rito do Jurupari (Hugh-Jones, 1979, p. 65). Para os Ticuna, a simbologia da dança das estrelas é associada à fertilidade das mulheres e da terra, representada como uma energia vital que se veicula nos caules, nas folhas e nos frutos de palmeiras, como buriti, malva e babaçu, utilizados em diversos momentos do ritual de puberdade. 
Priscila Faulhaber. “As estrelas eram terrenas”...

Durante esse ritual é encadeada uma seqüência de atos como os cantos, a reclusão da moça, a pajelança e a entrada das máscaras, que representam papéis relacionados com as expectativas da moça e do grupo ante às transformações climáticas, expressas em seus relatos e suas narrativas gráficas presentes na iconografia inscrita nos artefatos rituais (panos, máscaras e instrumentos).

Já foi apontado que o pensamento indígena funciona como "lógica do concreto" (Lévi-Strauss, 1962, p. 38). Em tal lógica, esse pensamento apreende o mundo por meio de um sistema de classificações (Cardoso de Oliveira, 1970, p. 53). No que se refere à cosmovisão, à antropologia do clima e à climatologia religiosa dos povos indígenas das terras baixas da América do Sul, existe uma vasta bibliografia a partir da qual será apresentada, num primeiro item, uma leitura, ainda que limitada, dos propósitos do presente trabalho. Num segundo item, serão expostos os procedimentos de pesquisa estabelecidos para interpretar esse imaginário.

\subsection{Leitura da bibliografia especializada sobre antropologia do clima e religiosidade climática}

Lévi-Strauss (1991, p. 11) mostra de que modo as categorias empíricas de culturas indígenas, observadas etnograficamente, servem como "ferramentas conceituais para isolar noções abstratas e isolá-las em proposições". Parte da relação entre os mitos da mesma sociedade, para mostrar conexôes entre mitos de diferentes sociedades, dentro do complexo social e cultural das terras baixas da América do Sul. Desmontando os mitos para analisar as variáveis com as quais são formulados, compara sua mitologia com "o estudo dos raios refletidos e refratados". Mostra a relação entre o pensamento mítico e as constelaçóes para variados povos, 
entre eles os Ticuna, citando relatos reunidos na monografia de Curt Nimuendaju sobre este povo. Examina as associações entre meteorologia e astronomia, detendo-se na comparação entre mitos sobre o arco-íris e sobre as diferentes constelações, correlacionando idéias e classificações nativas, a partir de observaçôes de fenômenos relacionados com as cores, as plantas, os animais, a terra, a alimentação, a saúde. Essas observações encontram correlatos em domínios de disciplinas, definidos pelas ciências ocidentais como botânica, zoologia, geologia, nutrição e medicina. Refere-se especificamente ao problema das conseqüências biológicas e econômicas do clima para as práticas e o pensamento indígena, comparando a oposição entre a estação das secas e a das chuvas para o Brasil Central e a Amazônia, do ponto de vista das relaçôes entre sazonalidade e abundância ou escassez de peixe (Lévi-Strauss, 1991, p. 225).

$\mathrm{Na}$ análise dos sistemas de classificação indígena, a relação com a natureza e as mudanças ambientais passa pela interação com as forças e os seres desconhecidos e pela mediação de especialistas nativos, os xamãs ou pajés, que controlam técnicas e saberes adquiridos pela experiência direta e transmitidos de geração a geração. Esses saberes e técnicas configuram-se em sistemas de pensamento, visão e reflexão do mundo, que integram dimensóes sociais e culturais e conferem especificidade à cosmovisão de cada povo etnicamente diferenciado. Tais especialistas formam-se em viagens de iniciação xamânica, que consistem na "transposição, sobre o plano material da 'viagem da alma”", e exprimem a vontade de ultrapassar os limites de tempo e espaço (Chaumeil, 2000, p. 100).

No estudo da história das religiōes sul-americanas, Sullivan (1988, p. 6) aponta a insuficiência dos esquemas classificatórios para dar conta da complexidade dos mitos e das práticas religiosas historicamente determinadas, fazendo-se valer da hermenêutica histórica, entendida como teoria interpretativa. Mostra também que muitos motivos e símbolos religiosos não se circunscrevem a religiōes delimitadas, uma vez que 
Priscila Faulhaber. “As estrelas eram terrenas”...

formas comuns de expressão religiosa emergem em povos e continentes bastante diferentes entre si, devendo ser examinados os processos históricos que determinam os empréstimos culturais, bem como as "estruturas míticas através das quais muitos povos sul-americanos avaliam sua existência no tempo", tanto pelas concepções dos tempos de criação por seus heróis quanto pelas que se voltam ao fim do mundo. O autor aponta também as lacunas dos documentos escritos nos quais se registraram a história colonial e as mitologias nativas, e com os quais se almeja compreender as bases do impulso criativo de povos que não podem ser entendidos a não ser dentro de uma dinâmica de alteridades.

Numa abordagem do estudo das formas de expressão simbólica e da imaginação nativa, não se devem desconsiderar influências de ordem emocional relacionadas com os confrontos, as aproximações e as disjunções entre o eu e seus outros, observáveis nos sonhos, êxtases, mitos e ritos, sejam eles presenciados ou não por um observador externo. Nas estórias de vida coletadas por antropólogos, muitas vezes se identificam comparações entre as peripécias de indivíduos concretos e as dos heróis míticos. Tal como analisado por Cipolletti (1991-1992), no que se refere às correlações entre as "façanhas" de narradores Secoya e os feitos dos "protagonistas da criação do cosmos”, que têm características semelhantes às das personagens das mitologias de muitos povos americanos.

A abordagem da "antropologia do clima" define-se no sentido da análise da relação "entre os fatores climáticos e as culturas humanas" enquanto uma "interação bidirecional". Entende-se clima como uma sucessiva "série de estados da atmosfera situada acima de um dado lugar” (Goloubinoff et al., 1997, p. 14). Do ponto de vista antropológico, consideram-se práticas e representações - por parte de representantes de povos indígenas determinados - sobre as transformações climáticas. A “adivinhação" e os "prognósticos" são formas de interpretar e definir a ordem da causalidade em relação aos elementos do clima, dentro de um 
sistema de classificações políticas, cuja ordenação determina as relaçōes entre os homens, a sociedade e o meio ambiente (Rivière, 1997). Isto toca os propósitos do presente trabalho no que diz respeito à abordagem das perplexidades diante da angústia e incerteza quanto à explicação e à solução de problemas relacionados às mudanças climáticas globais, sobretudo no que se refere às perspectivas de sobrevivência das novas geraçôes, o que envolve estratégias identitárias e culturais voltadas ao manejo de recursos econômicos.

Dentro da abordagem do climatismo religioso, Wilbert (1996) estabelece, ao analisar a religiosidade climática Warao, um exame comparativo dos saberes climatológicos na América do Sul. Seu principal objetivo é colocar a religião climática em um contexto continental, do ponto de vista da análise do enraizamento dos componentes autóctones desta religiosidade em uma matriz das crenças tradicionais do Novo Mundo. Seu objetivo secundário é isolar os elementos estrangeiros da religião climática e expor seu uso como empréstimos culturais. Mais do que considerar traços não característicos como possíveis invençôes locais, procura contextualizá-los com os saberes de outros continentes, considerando a importância da vida de fronteira na cultura Warao. No cumprimento desses objetivos, Wilbert tenta apreender a adaptabilidade humana Warao em termos do controle da fome, bem como demonstrar, por meio de conexões entre particularidades dispersas dos saberes climáticos em uma totalidade singular, o paradigma unificador da etnometeorologia. $\mathrm{O}$ autor aponta que a religiosidade climática se constitui como uma busca de proteção para a fome sazonal e a deficiência alimentar recorrente. A mitologia climática e seus rituais envolvem representaçóes relacionadas com problemas alimentares e a promoção de comportamento que conduza a este objetivo. Embora seja questionável a eficácia natural da climatologia religiosa, sua significação para a sobrevivência é evidenciada nas práticas sociais e na simbologia a elas referida. Interessa aqui reter 
Priscila Faulhaber. “As estrelas eram terrenas”...

que a religiosidade climática assinala um imperativo de sobrevivência: a busca de adaptação aos transtornos provocados pelas pesadas chuvas sazonais, bem como pelos vendavais ocasionais, que apresentam desalentadores prospectos de aflição crônica e deficiência alimentar endêmica.

A interpretação das práticas socioculturais com relação à sobrevivência Ticuna passa por técnicas orientadas pelos saberes para eles disponíveis, combinando as concebidas pelo conhecimento tradicional e as correntes na sociedade envolvente. Nem mesmo os especialistas Ticuna demonstram considerarem-se aptos a prever com precisão as mudanças climáticas, mostrando fatalismo em relação às mudanças ambientais. Sendo assim, para eles, o clima e os fenômenos atmosféricos estão relacionados a uma explicação de ordem mítico-religiosa e não se determinam simplesmente por meio da observação de posições geográficas particulares ou com a observação do movimento regular dos astros.

Os fatores climáticos são, segundo seus depoimentos, influenciados por seres que vivem em lugares míticos que interferem sobre os seres da terra, entre os quais se situam os humanos. Esses seres que controlam os fenômenos naturais são considerados como "donos" de cada fenômeno, ou seja, o "dono do vento", o "dono da chuva" e o "dono da mata". As prescrições rituais dizem respeito a evitar comportamentos considerados perigosos, que acarretem reaçóes desses seres, provocando assim as catástrofes que podem destruir o mundo.

Nos lugares míticos como montanhas, morros e lagos encantados, vivem os heróis culturais, espíritos e monstros que influenciam as mudanças atmosféricas e o calendário agrícola e extrativo. A eles correspondem os lugares identitários (Enepü, Otaware, Bunecü etc.), nos quais os Ticuna, que vivem conforme os ensinamentos de seus heróis culturais, procuram estabelecer-se. Esses locais têm relação com os lugares de ocupação Ticuna, que não pode ser dissociada do contato interétnico e da ocupação do território indígena por representantes da 
sociedade nacional. Nos relatos Ticuna, o tempo da mitologia está imbricado com acontecimentos históricos (Oliveira Filho, 1999, p. 30), observando-se a sobreposição entre lugares identitários e lugares da ocupação colonial.

A intervenção do próprio homem é percebida como um dos fatores que interferem na degradação do ambiente, colocando em perigo a saúde das pessoas. A pesca predatória nos lagos de procriação e a extração desordenada de madeira, efetivadas com a participação de alguns Ticuna, consistem em um fator de degradação ambiental. Falar do tempo é, de certo modo, dizer algo sobre as turbulências sociais, sobre as relações entre os homens, os espíritos e as divindades que regem o mundo. Por meio de tal fala, denota-se a importância da performance dos procedimentos rituais para afastar as calamidade e obter sucesso na agricultura, na caça e na pesca.

\subsection{Procedimentos de pesquisa: atefatos etnográficos, ação ritual e relatos Ticuna sobre as transformações climáticas}

O fato de haver presenciado, logo em minha primeira pesquisa no alto Solimões, em 1997, uma festa na comunidade Bunecü (Barro Vermelho) despertou o interesse sobre a relação entre as máscaras rituais e as expectativas sobre o meio ambiente. Naquela ocasião, alguns anciãos disseram-me que muitas máscaras tinham sido levadas para museus, e eles tinham interesse em rever as peças e mostrá-las para os jovens que não sabiam mais como fazê-las. Essa curiosidade voltou minha atenção às máscaras enquanto artefatos rituais transformados em peças etnográficas.

Após um survey no Museu Nacional em busca da iconografia das peças Ticuna coletadas por Curt Nimuendaju, dediquei-me, a partir de agosto de 1998, a um inventário dos artefatos desta mesma coleção 
Priscila Faulhaber. “As estrelas eram terrenas”...

depositados no Museu Goeldi. Acompanhada por bolsistas de iniciação científica ${ }^{3}$ e pelo museólogo Rubem Moura, examinei, ao todo, 48 indumentárias e complementos de dança e 48 instrumentos rituais.

Levei a campo fotografias e desenhos técnicos desses artefatos ${ }^{4}$. Procurei inicialmente mostrar os desenhos e as fotos aos índios com os quais eu tinha contato mais próximo. Em geral, eles ficavam interessados em perguntar aos anciãos o significado dos desenhos. Nas comunidades da Colômbia, eles convocaram reuniôes formais, convidando especialmente anciāos, professores e artesãos. No Brasil, as reuniōes eram realizadas com menor grau de formalidade, mas os anciãos não deixavam de ser convidados e pareciam mesmo imprescindíveis, uma vez que sem eles os mais novos não queriam falar sobre o significado das peças. Presenciei mais duas festas, uma na comunidade Ribeiro, em dezembro de 2000, e outra na comunidade Enepü, em julho de 2002. Nessas duas ocasiōes adquiri formalmente artefatos para o Museu Goeldi e solicitei que me explicassem o que significavam. Para atender minha solicitação, convidaram anciãos para falar sobre o significado dos artefatos e o contexto no qual foram produzidos.

O inventário culminou com uma avaliação dos artefatos por seis representantes Ticuna, presentes na oficina "Os índios Ticuna e a Coleção Nimuendaju do Museu Goeldi”, realizada em Belém de 26 de novembro a 16 de dezembro de 2002. Participaram dessa oficina três Ticuna colombianos (um professor, um desenhista e um estudante de graduação em lingüística da Universidade Nacional da Colômbia) e três brasileiros (uma anciã e um casal de especialistas Ticuna, que realizou a tradução dos depoimentos da anciã). A lingüista Marília Facó Soares, especialista em lingüística Ticuna do Museu Nacional (UFRJ), participou de todas as etapas dessa oficina, elaborando um inventário lexical com os termos Ticuna formulados quando eles examinavam os artefatos rituais (Faulhaber, 2003). 
Para interpretar o imaginário contido na iconografia dos artefatos rituais, os Ticuna, portanto, buscaram os setuagenários - cujos depoimentos em Ticuna foram traduzidos por representantes Ticuna que dominam o português. Considerando-se que em cada festa são apresentadas diferentes versões dos mitos de origem, a memória desses anciãos é um repositório de informações valiosas sobre a cultura Ticuna que se deseja aqui interpretar, uma vez que acompanharam festas de moças de pelo menos três gerações consecutivas e eles já eram adolescentes quando o etnólogo alemão Curt Nimuendaju (1882-1945) ali esteve, em 1941, 1942 e 1945, coletando peças e realizando a pesquisa para sua monografia - consagrada, sobretudo, pelo estudo minucioso da mitologia Ticuna -, cuja presença imprimiu na memória Ticuna aspectos de sua performance como "ator social" (Oliveira Filho, 1945, p. 62).

Entende-se a performance ritual como um desdobramento da experiência (Turner, 1982, p. 13); e considera-se, na conceituação de performance, a significação dos mitos e seus enunciados prescritivos, tal como presentes nas fórmulas cantadas, bem como a interação entre diferentes esferas de participação e audiência (Tambiah, 1985, p. 125). A realização da festa é considerada fundamental para a formação da pessoa Ticuna. A partir do estudo minucioso dos próprios termos Ticuna, que não cabe aqui reproduzir, Goulard (1998, p. 11-2) mostra os princípios sobre os quais repousa a formação da pessoa. A "força vital", sobre a qual repousa a manutenção da pessoa, adquire-se e renova-se por meio da alimentação e dos rituais. Esse "princípio de força”, possuído pelo corpo, permite a aquisição e manutenção de uma "energia", assegurada por uma "alimentação" consumida no quotidiano ou fora dos rituais. Sem essa energia, não há vida possível. A "essência vital” (diferente de "energia") é o resultado das interaçóes da pessoa com o meio, povoado por seres que também a possuem. 
Priscila Faulhaber. “As estrelas eram terrenas”...

As estórias cantadas e relatadas no decorrer da festa referem aos mitos de origem desse povo e são uma forma de transmitir tais concepções de geração a geração (Faulhaber, 1999). Essas estórias incluem representações sobre figuras fronteiriças, que dizem respeito ao contato com a sociedade nacional. Essas figuras, que aparecem em narrativas orais e gráficas, relacionam-se ao imaginário Ticuna e ao imaginário das fronteiras nacionais e das fronteiras étnicas (Faulhaber, 2001). Parte-se da idéia de que nos lugares de fronteira manifestam-se relações entre identidades, uma vez que sujeitos sociais constroem sua auto-imagem por meio da negação, da aceitação ou da exclusão do Outro. A figura do inimigo primordial é associada, nos relatos Ticuna, aos Omáguas, Cocamas e Cambebas. Esses índios também aparecem nos documentos históricos como inimigos dos Ticuna anteriormente ao contato com os brancos, cuja presença na história da colonização redefiniu o quadro dos conflitos interétnicos, tal como foi apontado por Cardoso de Oliveira (1972). A análise da cultura de fronteira considera a importância de se levar em conta necessidades e desejos, no âmbito do imaginário dos índios, que expressam a relação fronteiriça entre natureza e cultura, cujo estudo já foi consagrado como objeto da antropologia.

$\mathrm{Na}$ festa da moça manifesta-se uma postura do grupo no ritual em face das transformações climáticas. Quando a moça sai do recinto de reclusão, entram em cena os mascarados, que encenam os perigos da floresta que ameaçam a vida societária Ticuna, como a chegada de intempéries. Existe uma ordem de entrada das máscaras (Faulhaber, 2002): os primeiros ventos (Toü) anunciam a chegada da chuva (Mawü), do vendaval (O’ma) e, por fim, da tempestade (Yureu), a última máscara que aparece acompanhada da roda, a qual significa que ao término do ritual os Ticuna estão protegidos ${ }^{5}$. A festa como um todo consiste em um rito de fertilidade que se apresenta também como um rito agrícola e 
pesqueiro, uma vez que os Ticuna afirmam que sua realização acarreta sucesso na caça, na pesca e na agricultura. Durante todo o ritual, aparecem representações relacionadas com a visão de mundo Ticuna, bem como do movimento dos corpos celestes e da relação com a natureza (Faulhaber, 1999). Na iconografia Ticuna, além de imagens de corpos celestes, registram-se desenhos de seres antropomorfos, fitomorfos e zoomorfos, entre estes últimos encontrando-se referências a répteis (cobra, jacaré, calango), aves (águia, gavião, urubu) e mamíferos (onça, macaco, tamanduá).

\section{O ritual e suas máscaras: observações para uma etnografia do imaginário das transformações climáticas}

Trata-se de problematizar observações de campo sobre o imaginário das transformações climáticas, bem como considerar os contextos sociais dos artefatos rituais com base nos significados a eles atribuídos pelos próprios especialistas Ticuna, que manejam o conhecimento cosmogônico, do ponto de vista da especificidade de sua cultura e organização social, o qual determina o lugar de tais artefatos no ritual da puberdade feminina.

Serão apresentados, primeiramente, registros etnográficos da primeira metade do século XX, comparáveis com o que se entende hoje sobre a religiosidade e as classificaçôes climáticas Ticuna. Serão expostas, a seguir, as observaçóes de campo produzidas nesta pesquisa do ponto de vista das relações entre festa e religiosidade climática, com o intuito de tratar de alguns artefatos que se mostram interessantes para pensar aspectos da cosmovisão Ticuna, com o enfoque das indagaçóes expostas acima, a partir de uma leitura da bibliografia especializada. 
Priscila Faulhaber. “As estrelas eram terrenas”...

\subsection{Calendário agrícola, messianismo e pragmatismo na etnografia Ticuna}

Fidelis de Alviano (1943, p. 16) refere-se ao conhecimento Ticuna dos fenômenos da natureza, como a recorrência da realização de festas no plenilúnio, a noção da hora pela posição do Sol, o prenúncio, com acerto, das mudanças atmosféricas, utilizando-se como sinais sobretudo o movimento e o canto das aves. Os gritos dos guaribas também constituem sinais do percurso diurno do Sol, no quase permanente equinócio equatorial. $\mathrm{O}$ autor observa a existência de um calendário para o cultivo agrícola e para as atividades extrativistas; o conhecimento da enchente (de janeiro a junho) e vazante (a partir de junho); o tempo das praias e dos tabuleiros de tartarugas (agosto); o tempo das gaivotas e dos tracajás (setembro); o tempo das tartarugas ou de viração (até fevereiro); o tempo de sorva (dezembro, janeiro e fevereiro); o tempo das sapotas (março e abril) e dos repiquetes (cheias) intermediários, que podem ocorrer após a vazante ${ }^{6}$.

Os usos desse calendário ainda se observam nos dias de hoje, notando-se, no entanto, que as cheias e vazantes se apresentam mais acentuadas, sobretudo a partir das duas últimas décadas. Não se trata de uma progressão anual, mas o registro de grandes cheias, ainda que intercaladas com outras não tão marcantes, tem crescido de forma notável, segundo as representações tanto dos Ticuna, do alto Solimões e da Colômbia, quanto dos Miranha, Cambeba e Mayorúna, no médio Solimões.

A etnografia Ticuna de Nimuendaju destaca processos ainda operantes nos dias de hoje, como aspectos de sua visão de mundo. Em manuscrito redigido para o Handbook of South American Indians, assinado em Belém (1943, p. 82), atualmente depositado no Arquivo Nimuendaju do Museu Nacional, o autor refere-se à "lenda do incêndio do mundo com subseqüente dilúvio", que trata da "possibilidade de uma repetição 
dos cataclismos de tempos antigos". Ainda, segundo Nimundaju, aqueles que vêem em sonhos os imortais afirmam que "um cataclismo eminente destruirá os civilizados" e os meios para os índios se livrarem do desastre são, em geral, "a reunião num local indicado ao abrigo dos cataclismos, e a performa [nce] de certas cerimônias".

Uma outra versão da referida lenda, registrada em setembro de 1998 na terra indígena Évare II, aldeia Otaware, repete o tema do mito bíblico do dilúvio, que permeia o imaginário dos movimentos socioreligiosos de povos indígenas em estados nacionais ibero-americanos (Barabas, 1989). Tais representaçôes são apresentadas em termos de uma "imaginação concreta" alimentada por utopias étnicas, tal como analisado por Barabas (1986), a partir de discussão sobre o conceito de "utopias concretas" de Bloch (1979). O pensamento utópico, enquanto vontade de concretização dos sonhos étnicos (e sociais) (Faulhaber, 1994, p. 177), permeia, por exemplo, as estratégias Ticuna com base em suas expectativas a respeito das conseqüências da chegada das chuvas, das quais eles dependem, mas cujo excesso lhes traz conseqüências nefastas, o que lhes faz viver na ânsia de que estão sujeitos a calamidades e à possibilidade de cataclismos, como representado na "lenda do dilúvio". Oliveira Filho (1988) indica como se registram hoje "movimentos de busca de salvação" relacionados à afirmação da identidade Ticuna. Nesses movimentos, objetivos pragmáticos de fundo racional alternam-se com valores milenaristas de fundo religioso, sem que haja necessariamente vinculação direta ao movimento messiânico da Cruz, à Igreja Católica ou às igrejas pentecostais, conforme observei em estadias nas comunidades do Enepü (Morro da Formiga), Otaware (Gente do Morro) e Bunecü (Barro Vermelho).

Acompanhei, ao longo de minhas pesquisas com os Ticuna, um movimento que se enquadra como identitário-pragmático. Quando Pedro Inácio Pinheiro saiu da comunidade de Vendaval, onde era capitão, instalou-se no Enepü, na terra indígena Évare II, com sua família. 
Priscila Faulhaber. “As estrelas eram terrenas”...

A partir daí passaram a migrar para esse lugar anciãos que cultivam os valores do povo Magüta. O Enepü, localizado na cabeceira do igarapé Canela de Nego Preto, corresponde a um lugar identitário onde, segundo relatos míticos, foram encontrados vestígios de antigos escravos foragidos. Esse local corresponde à última colocação do Seringal Ribeiro, região onde hoje existe uma comunidade Ticuna. $\mathrm{O}$ retorno aos igarapés que evocam a imagem do Eware, no entanto, não se reduz à busca da recriação de uma comunidade mítica originária, uma vez que os Ticuna que habitam nas cabeceiras dos igarapés dependem de sucessivas viagens aos centros urbanos, nos quais têm acesso aos bens necessários à sua sobrevivência física e cultural.

\subsection{As festas observadas e a religiosidade climática}

A encenação cronometricamente precisa da festa de Tóoena na comunidade Barro Vermelho, conforme observado em pesquisa de campo, durante o equinócio de setembro de 1997 , levou à suposição de que esta data seria um elemento definidor de momento propício à realização da festa, uma vez que o céu estando no zênite permitiria a execução de práticas simbólicas relativas ao controle de fenômenos climáticos, como a quantidade de chuva, cujo excesso é considerado motivo de temor pelas conseqüências que pode trazer em termos de destruição de moradias e de colheitas. No entanto, o equinócio não parece um critério definidor para a realização da festa, uma vez que, em anos posteriores, a mesma não se efetivou necessariamente nesta data.

Os Ticuna afirmam que se deve fazer a festa após a menarca de uma adolescente. A partir desse momento, prescreve-se que o pai dela deva acumular farinha e alimento suficientes para oferecer aos convidados, durante um período que geralmente dura de um a seis meses. Sendo assim, o 
período da estiagem é considerado propício para a execução da festa, uma vez que há mais disponibilidade de caça e pesca. Freqüentemente, realizam-na durante o início do verão, quando o rio ainda não está completamente seco, o que dificultaria o deslocamento dos convidados. Afirmam preferir as noites de lua cheia por causa da luminosidade noturna.

Quando preparavam a festa de Tueguna, em julho de 2002, no Enepü, o pai da moça afirmou que queria realizar a cerimônia antes que o rio secasse muito porque, uma vez que o Enepü localiza-se na cabeceira do igarapé Canela de Nego Preto, na montante do remanso do Ribeiro, com a seca e a distância, o deslocamento dos convidados seria dificultado. Marcaram a festa para o final de julho. No entanto, ocorreu a partir de meados de julho um repiquete imprevisto ${ }^{7}$ - que normalmente ocorre só em setembro -, fazendo subir em dois metros o nível do Solimões e em meio metro o nível do igarapé Canela de Nego Preto. Já que o repiquete provoca escassez de pesca, os Ticuna o consideraram como uma anomalia causadora de moléstias, como a da mãe de Tueguna, que se deslocou a contragosto para São Paulo de Olivença, cidade mais próxima, onde foi hospitalizada com diagnóstico de leishmaniose, o que a impediu de participar da festa da filha. Em virtude da ausência da mãe de Tueguna, os convidados entregaram as máscaras e vestimentas ao pai, mas não desempenharam performance ritual com elas, como estava previsto, para evitar maiores males, uma vez que choveu muito durante toda a realização da cerimônia, o que é considerado anormal em julho, mês de vazante. No entanto, registrou-se um depoimento no qual se informou que a partir de julho efetivamente ocorrem fortes chuvas mensais. Esses registros levam a confirmar a suposição exposta acima de que entre os motivos para realizar a festa destaca-se a vontade de deter um maior controle das relaçóes com o meio ambiente, sobretudo no que diz respeito à influência de fenômenos atmosféricos para a vida social. 
Priscila Faulhaber. “As estrelas eram terrenas”...

A cerimônia começa oficialmente com um brinde de pajuaru (bebida fermentada azeda) na casa do pai da moça, que confere autoridade ao dirigente da festa, chamado de "dono da festa", preferencialmente o tipo paterno da moça, a quem cabe receber os convidados e servir-lhes comida e bebida. Com o acúmulo de atribuições no decorrer da festa, esse pode não conseguir corresponder à demanda de seus participantes, que também o chamam de "garçom" ou "copeiro", evidenciando-se que, durante a cerimônia, se extravasam as tensões sociais, bem como as manifestações de insatisfação diante do fato de que os acontecimentos não se desdobram como seria desejável. Rala-se jenipapo para a pintura facial dos parentes e convidados. Estes últimos também são recebidos pelos líderes políticos da festa de sua metade. Trazem feixes de fibras de palmeiras (tucum, buriti, babaçu) preparados pela irmã do pai da moça. Essas palmas, associadas ao simbolismo da fertilidade, são utilizadas em danças rituais. Ao chegar, eles são conduzidos ao lugar no qual devem colocar suas redes. A moça é reclusa em um recinto construído com talas de buriti e teto de palha de caraná, no qual somente podem entrar seus parentes mais próximos, como pai, mãe, tios, tias, avós e avôs, que lhe contam histórias de advertência e cantam para ela cantigas com os enunciados míticos. Cabe à mãe e à avó materna proteger a moça. Em um cercado anexo são guardados os intrumentos to' cü e buburi (uaricana macho e fêmea), tocados no início da noite. Durante o corte do naitchi (tronco ritual de envira, com cuja casca é preparado o material usado para tecer o cocar e a tipóia), os participantes da festa começam a entoar cantigas que exprimem em geral grande tristeza, com enunciados míticos interpretados conforme aventuras pessoais. Realizam rituais de pajelança para chamar os seres da floresta e alimentá-los. As primeiras máscaras aparecem rapidamente quando a moça é tirada da reclusão para a pintura corporal e para o corte do cabelo da criança - que também está sendo iniciada durante a festa e na qual será colocado um brinco - e reapare- 
cem quando ela é retirada da clausura para a depilação, dançando com ela após seus cabelos serem arrancados e seu cocar ser colocado. O simbolismo dos cabelos está associado ao simbolismo do sangue menstrual, da chuva, da purificação enquanto fatores associados à fertilidade da mulher e, em um mecanismo de substituição ritual, da natureza.

O cocar da moça, cujas penas, de arara vermelha, representam o sol, é preparado pela manhã. Ele é colocado nela assim que a retiram definitivamente do curral e antes da depilação. Os olhos da moça devem estar, durante todo o tempo, tampados, pelas próprias mãos, as de seu irmão ou pelo cocar, para evitar calamidades que, segundo dizem, irão ocorrer se ela olhar ou for olhada pelos convidados ou mascarados, que representam os seres invisíveis da floresta. Temem as calamidades, sobretudo por causa da fome ou de moléstias a ela associadas.

Observa-se a adaptação das técnicas de agricultura e estoque de farinha de mandioca para consumo durante épocas de carência alimentar, sobretudo na estação das chuvas, quando os peixes e as frutas tornam-se mais escassos. A formação do estoque de farinha envolve procedimentos de colheita, social e politicamente estruturada, enquanto uma responsabilidade comunitária, ainda que sejam aparentemente mais simples do que outras técnicas de estoque difundidas em áreas tropicais, como o das fibras de palmeiras utilizadas para alimentação, construção de residências e adornos.

As evidências etnográficas levam a supor que as técnicas da estocagem de farinha para a realização da festa estejam associadas ao culto do povo Magüta - pescado pelos heróis culturais Yoi e Ipi. Tal como em outras formas de religiosidade climática, estratégias associadas à busca de lugares de abundância, estabelecendo-se nos santuários de seus territórios identitários, tornam-nos menos vulneráveis à fome sazonal.

As inovaçôes introduzidas por influências externas tiveram impacto nas crenças climáticas por meio de um processo de adaptação, 
Priscila Faulhaber. “As estrelas eram terrenas”...

recolocaram o climatismo religioso em termos de práticas sincréticas voltadas à sobrevivência. Ainda que os missionários tenham induzido os Ticuna a não fazer os rituais, os grupos arredios continuavam praticando-os, associando-os a estratégias de sobrevivência nas áreas das florestas próximas às cabeceiras dos igarapés, onde podiam sobreviver apesar da exploração dos patrões. No entanto, era impossível romper totalmente com a cultura do contato, uma vez que já conheciam o sistema de aviamento e o consumo de mercadorias manufaturadas. Absorveram, desse modo, técnicas como a salga e a estocagem de peixes cobiçados comercialmente, como o pirarucu e o tambaqui.

\subsection{Artefatos rituais e representações Ticuna sobre o movimento dos corpos celestes, meteorologia e sazonalidade}

A percepção de que os Ticuna desenvolvem concepções sobre o movimento dos corpos celestes estabeleceu-se a partir da primeira oficina com desenhos e fotos das peças da Coleção Nimuendaju em Nazaret, em 1999, na qual eles teceram comentários sobre a roda, que representa o "mundo com as estrelas" (reproduzida abaixo).

A figura do primeiro quadrante foi associada a Baweta (coletivo de tartaruga), e o traço próximo à circunferência a Coyatchicüra (queixada do jacaré). No segundo quadrante, a estrela Woramacuri (estrela da moça nova/estrela da manhã) e de novo Coyatchicüra. No terceiro quadrante, Emarüta, Wü̈cütcha (fera celeste associada ao clã onça) e Coyatchicüra. No quarto quadrante, Emacüari e Coyatchicüra. A análise dessas representações, em sessões de cúpula em planetário, levou à suposição de que essa roda corresponde ao movimento da "Queixada do Jacaré” ao longo do ano. Um artesão Ticuna desenhou-a em 1941, data na qual Júpiter e Saturno estavam em Touro. No ano 2000, esses 


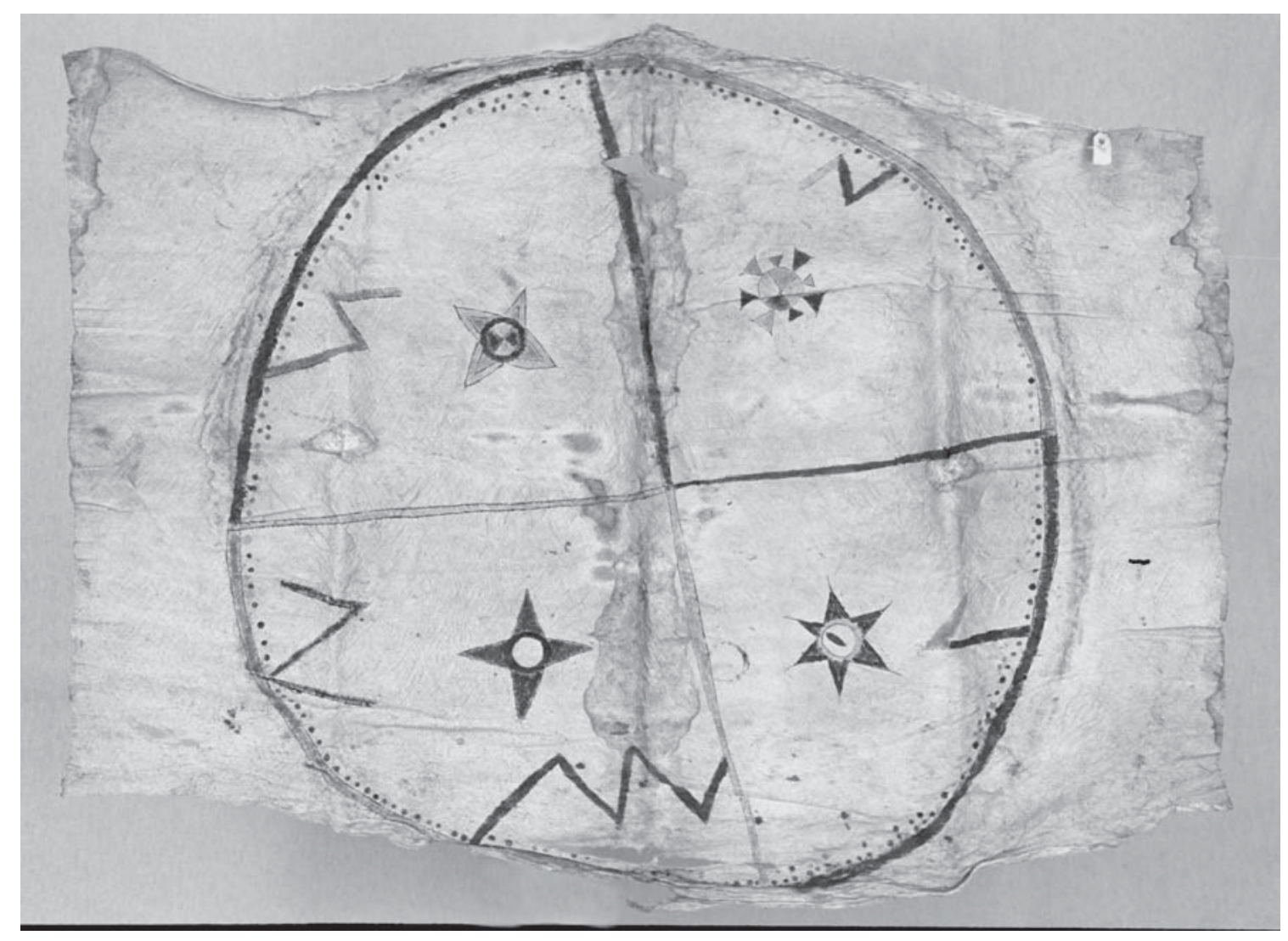

Pano, Museu Goeldi, RG 4046

dois planetas estavam novamente em Touro $^{8}$, o que me levou à consideração de que o narrador Ticuna, Francisco Batista, de aproximadamente 70 anos, em oficina na comunidade colombiana de Nazaré, falava também do curso dos acontecimentos na trajetória de sua vida.

$\mathrm{Na}$ festa de Boatana me'ta' na', realizada na comunidade do Ribeiro no dia 31 de novembro de 2000, coletaram-se para a coleção etnográfica do Museu Goeldi artefatos, dos quais selecionam-se aqui alguns, descritos a seguir pela ordem de entrada, tal como comentado por Benedito Cosme André, capitão de Barro Vermelho: 
Priscila Faulhaber. “As estrelas eram terrenas"...

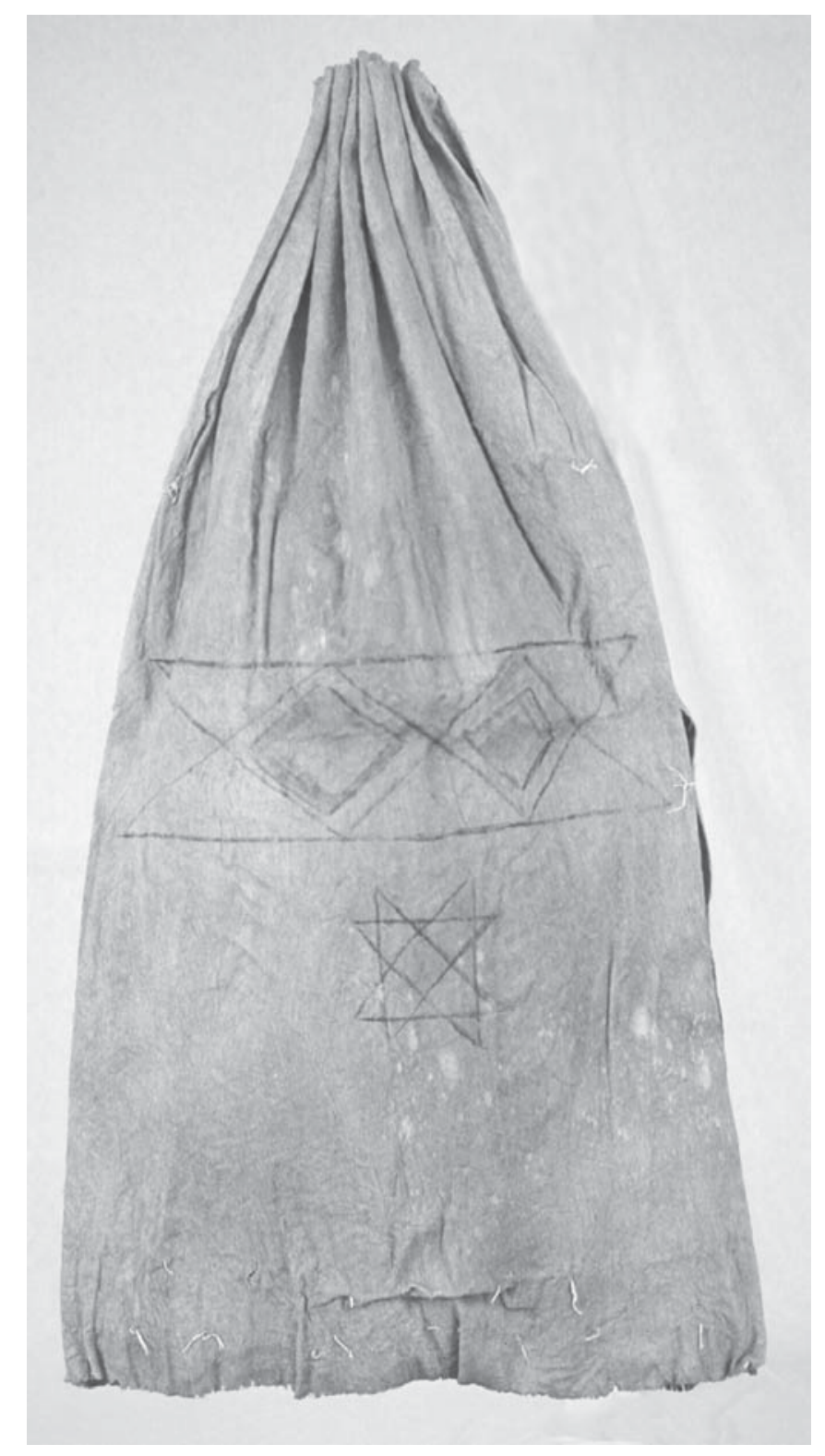

Vestimenta da máscara Nayu

O desenho da indumentária ritual Toü (feita de pau-de-balsa) referese a Nayu (índio brabo). No corpo, feito de caxinguba vermelha, descreve-se uma pinta de cobra jibóia e a estrela Woramacuri, sempre associada à estrela da manhã e à moça nova. 
Revista de Antropologia, São Paulo, USP, 2004, v. 47 № 2.

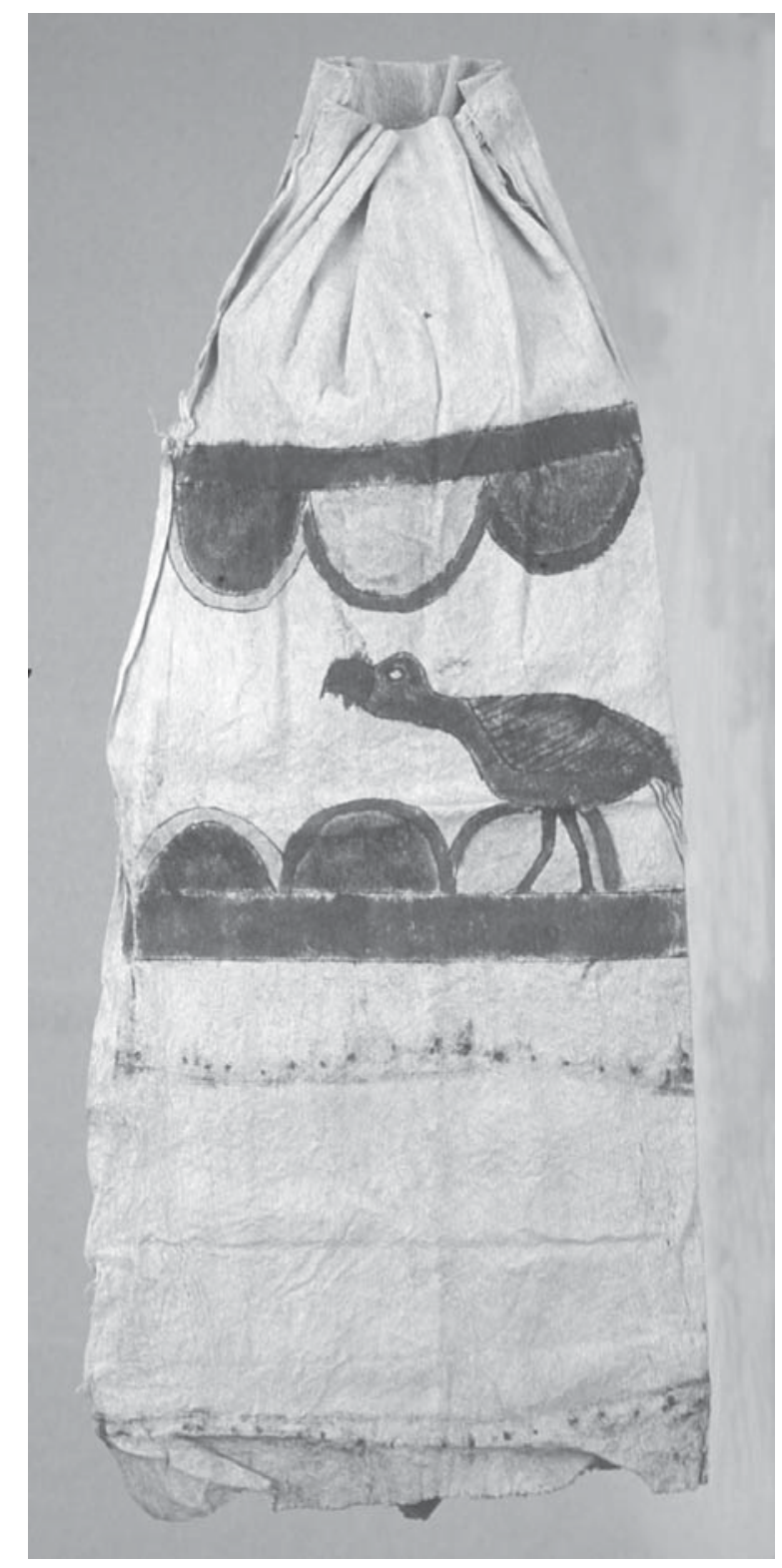

Mãe do Buriti

O desenho desta indumentária Toü refere-se a um pássaro - o piuri, da família do mutum, comparado pelo intérprete ao gavião real, que, em um fragmento mítico, trouxe para o povo Magüta as sementes das plantas que eles cultivam. 
Priscila Faulhaber. “As estrelas eram terrenas”...

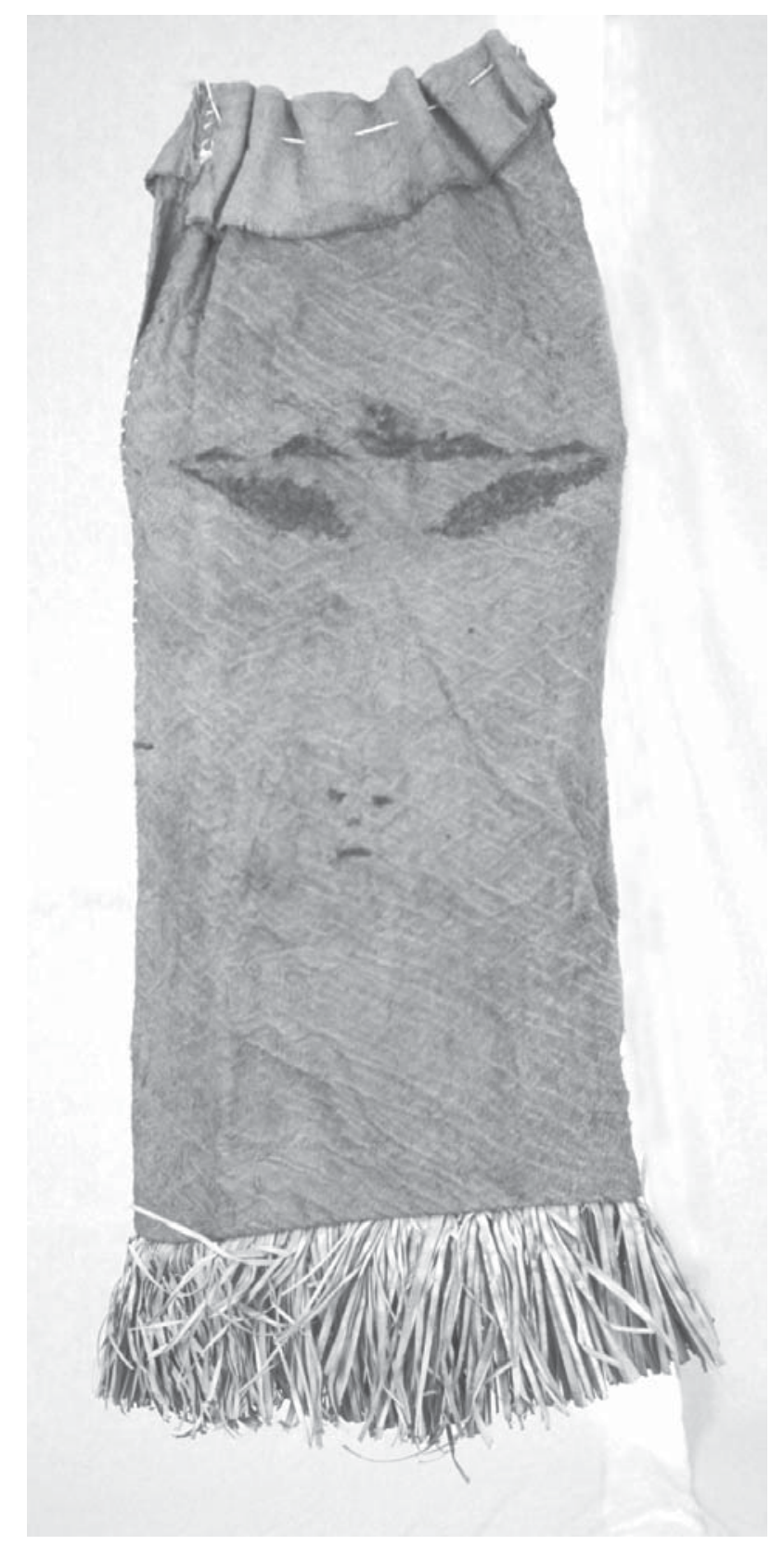

Emacüari e vampiro

Na parte superior, desenho de morcego Nütchi (Vampirum spectrum, chamado pelos Ticuna de mürieto). Abaixo, estrela Emacüari (seis pontas, com rosto humanizado). 
Revista de Antropologia, São Paulo, USP, 2004, v. 47 № 2.

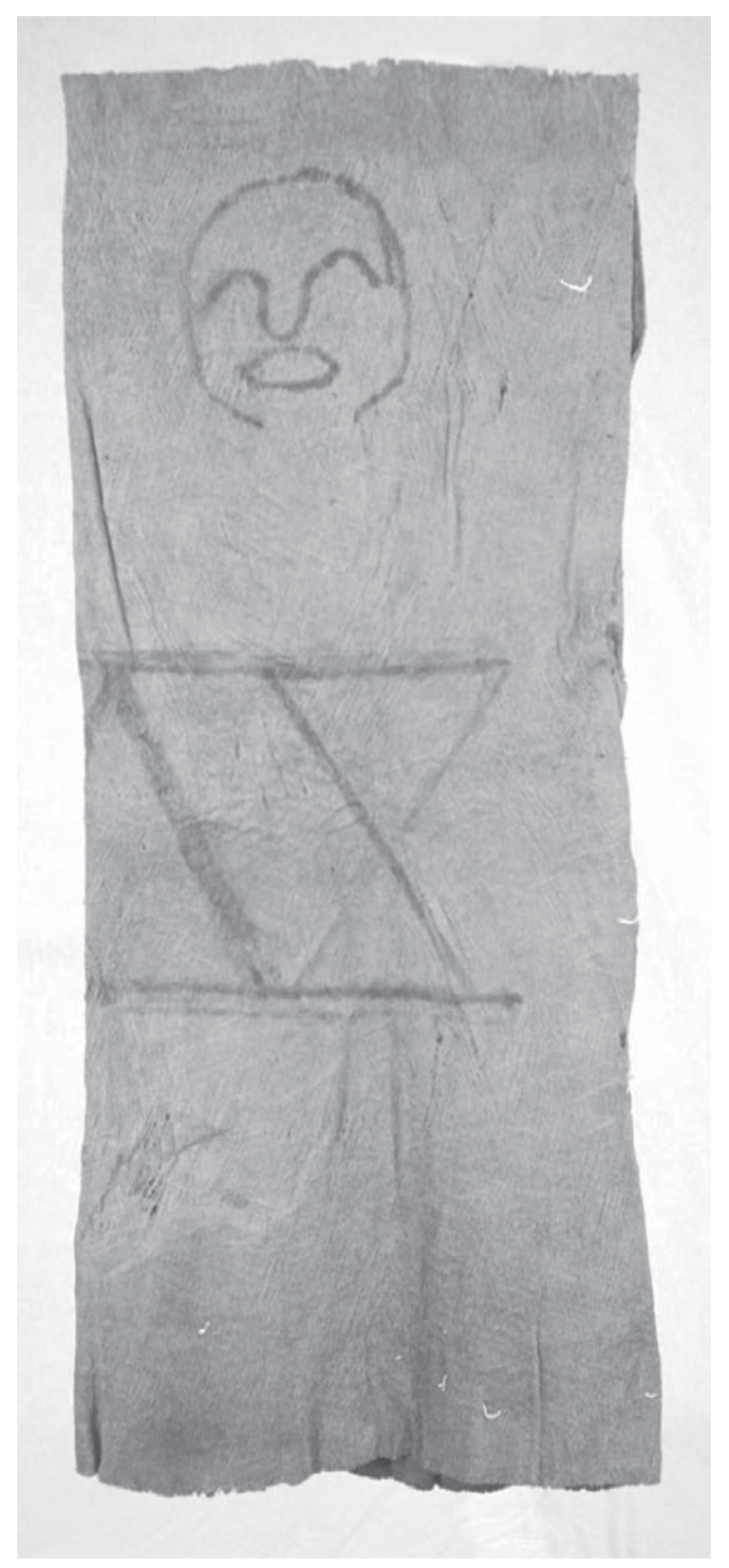

Filho de Lua/arco-íris

No complemento de máscara acima, nomeado como "vestimenta de Yureu", destacam-se a figura de um "filho de Lua" (Emarüta) e, abaixo, a iconografia do arco-íris (Woratchicuri). 
No escudo ou na roda (ver abaixo), a pinta de jibóia na qual estão desenhados, em torno do corpo celeste Emarüta ou Éta, os eixos em que gira o mundo, que, igualmente, simboliza o mundo (naane), representada com três pontas: a noite, de cor preta, o entardecer, de cor laranja, e o dia, amarelo. Esse processo ocorre na terra (waimü). O eixo do Universo é representado como um canal que conduz a luz solar pelos diferentes mundos, pelo qual circulam as energias vitais cujo fluxo penetra as moças púberes. Essas energias unem-se na cuia celeste com o "Caminho da Anta" (que corresponde à Via Láctea) e com a base do mar primordial, onde nasce o arco-íris (Camacho, 2003, p. 3). O pensamento do pajé, que aparece ao final com a roda presa com armação de arame, dando a impressão de um prolongamento das costas, tem o poder de percorrer o eixo do mundo e manejar as forças vitais. O aparecimento do arco-íris significa que o mundo ainda não acabou, bem como que a moça e seu grupo de referência estão fora de perigo.

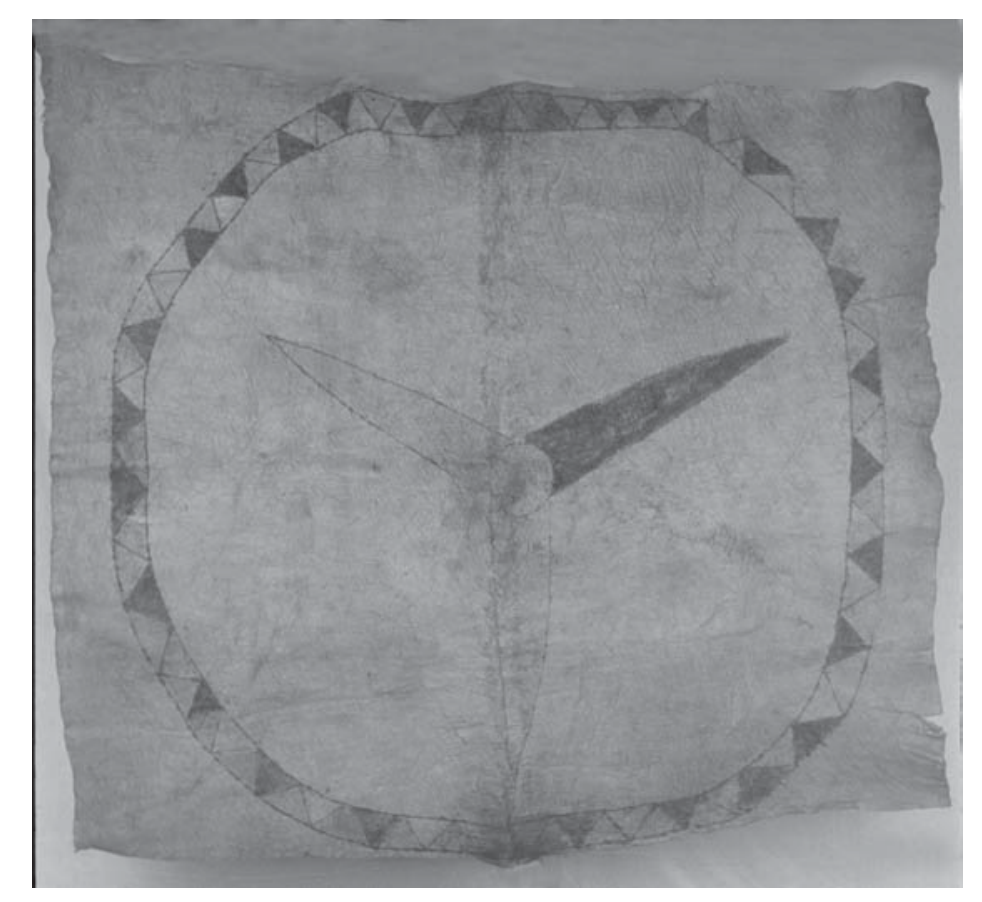

Roda da máscara Yureu 
Quando ocorreu essa festa, em dezembro de 2000, Júpiter e Saturno estavam em Touro, constelação que, na astronomia Ticuna, corresponde à representação do movimento celeste da "Queixada de Jacaré" (Coyatchicüra), o que levou à suposição de que os nomes Emarüta e Emacüari corresponderiam, respectivamente, a estes dois planetas, ainda que o significado a eles atribuído esteja associado à idéia de seres ou corpos que vivem no "mundo de cima" (primos maior e menor da estrela da manhã/filhos de Lua), sendo também relacionados a Yacürana9 e considerados seres que interferem na formação da pessoa. Esses seres são diferentes das estrelas cadentes (tchitacüü), comparadas ao "galho de envira que não quebra, isto é, que está dependurado, não cai e não morre". Todas essas entidades são denominadas pelo termo genérico referente a estrela (E'ta).

O quadro I, apresentado a seguir, consiste em um exercício de sistematização da classificação dos artefatos pelos Ticuna, relacionando o nome apresentado, os motivos iconográficos, sua descrição em narrativas Ticuna e as associações inferidas pelos próprios Ticuna.

\section{Quadro I: Artefatos rituais e motivos narrativos}

\begin{tabular}{|c|c|c|c|c|}
\hline Artefato & Nome & Motivo & Descrição & Associações \\
\hline indumentária & Toü (Macaco) & $\begin{array}{l}\text { Nayu } \\
\text { estrela } \\
\text { Woramacuri }\end{array}$ & $\begin{array}{l}\text { índio Bravo } \\
\text { oito pontas, } \\
\text { rosto humano }\end{array}$ & filho de Lua \\
\hline & Toü (Macaco) & Piuri Dawü & $\begin{array}{l}\text { família mutum } \\
\text { gavião real }\end{array}$ & $\begin{array}{l}\text { sementes } \\
\text { cultivadas }\end{array}$ \\
\hline indumentária & $\begin{array}{l}\text { Yureu } \\
\text { (pajé/xamã) }\end{array}$ & $\begin{array}{l}\text { Nüchii/mürietu } \\
\text { estrela Emacüari }\end{array}$ & $\begin{array}{l}\text { rei dos morcegos } \\
\text { seis pontas, } \\
\text { rosto humano }\end{array}$ & $\begin{array}{l}\text { Büanecü/ventania } \\
\text { primo menor } \\
\text { Yacürana } \\
\text { filho de Lua }\end{array}$ \\
\hline
\end{tabular}


Priscila Faulhaber. “As estrelas eram terrenas”...

$\begin{array}{lllll}\begin{array}{l}\text { Artefato } \\ \text { indumentária }\end{array} & \begin{array}{l}\text { Nome } \\ \text { Yureu } \\ \text { (pajé/xamã) }\end{array} & \begin{array}{l}\text { Motivo } \\ \text { Emarüta } \\ \text { Woratchicuri }\end{array} & \begin{array}{l}\text { Descrição } \\ \text { rosto humano } \\ \text { arco-íris }\end{array} & \begin{array}{l}\text { Associações } \\ \text { filho de Lua } \\ \text { incesto }\end{array} \\ \text { escudo } & \text { Natchime (roda) } & \text { Emarüta } & \begin{array}{l}\text { três pontas, } \\ \text { rosto humano }\end{array} & \begin{array}{l}\text { primo maior } \\ \text { Yacürana } \\ \end{array} \\ & & & \begin{array}{l}\text { filho de Lua } \\ \text { eixos do mundo }\end{array}\end{array}$

Os motivos apresentados no quadro acima são associados a signos presentes na mitologia da criação do cosmos. O índio bravo e o rei dos morcegos são figuras recorrentes das mitologias dos tempos de criação. O piuri e o gavião real, que são epônimos clânicos, representam a conjunção entre o "mundo de cima" e as atividades de subsistência, com o advento das plantas cultivadas. Os corpos celestes com rosto humanizado evocam o incesto primordial. São apresentados como consangüíneos (primos/irmãos/filhos de Lua). Assim como o arco-íris, servem como marcadores de tempo e são associados a transgressões cometidas pelos humanos, que provocam desastres e fenômenos cujo controle escapa da esfera de relações regulares.

\section{Relatos sobre os corpos celestes e as constelações Ticuna: correlaçóes do ponto de vista da sazonalidade}

As representações sobre corpos celestes são recorrentes do imaginário Ticuna, conforme se depreende da leitura de relatos sobre "lendas dos corpos celestes e fenômenos relacionados”, já registrados por Nimuendaju, entre os quais se destacam "a Canoa do Sol", "as Sombras da Lua", a "Onça e o Tamanduá" (Nimuendaju, 1952, p. 142-4). Fragmentos desses relatos foram registrados nas pesquisas de campo desde 1997, bem 
como outros a eles correlatos, tal como as referências a passagens entre céu e terra, que influenciam os ventos causadores de chuva e vendaval.

Em pesquisa de campo em maio, junho, julho e agosto de 2002, obteve-se uma série de versōes sobre a relação entre a Lua, o Sol, a Terra, o movimento das constelações e o fim das chuvas, associado à abundância de caça e pesca, e a época da volta das chuvas, um período de escassez. Essas narrativas dizem respeito às expectativas Ticuna em relação à meteorologia e suas conseqüências para o calendário agrícola e extrativo, a caça e a pesca. Segundo os relatos, em tempos primordiais todos os animais viviam no caminho da anta. Destacam-se as narrativas sobre a Lua, Wü̈ütcha, Coyatchicüra, Baweta, que correspondem ao início e fim das chuvas, e a história da luta da onça (Ai) e do tamanduá (Tchatü), que transcorre durante o período de estiagem e é apresentada em termos dos antecedentes da subida de Wǘcütcha. Primeiramente, serão apresentadas algumas reflexões a partir do exame de relatos Ticuna. Em um segundo item, serão mostradas as correspondências entre suas constelações e as constelações convencionais.

\subsection{Os relatos}

Os Ticuna afirmam que corpos celestes como a Lua e o Sol são seres vivos, cujos humores e atitudes interferem no destino humano; e os mitos a eles relacionados integram a cosmovisão que explica a origem e o devir do Universo, e dizem respeito a fatos da vida cotidiana relacionados com a cultura material e as estratégias de sobrevivência.

Lua, um jovem do gênero masculino, é responsável pela menstruação das mulheres. Quando desaparece do céu é porque desceu à Terra para abusar das mulheres jovens. As estrelas Woramacuri, também chamadas de "filhos da lua", são o resultado de transgressóes sociais, 
Priscila Faulhaber. “As estrelas eram terrenas”...

relacionadas à união incestuosa dos filhos de Lua, varôes chamados de Woramacüri e Womatchi (termo que significa "carne torcida"), segundo as observações no trapézio amazônico (Camacho, 2003, p. 8). Em interpretação do pano 4268, durante a oficina realizada no Museu Goeldi, os Ticuna introduziram um terceiro irmão, denominado Wora (termo que significa em português "ondeante", "tremulante"). A esses seres corresponderiam os termos Emarüta e Emacüari (primo maior e primo menor, respectivamente).

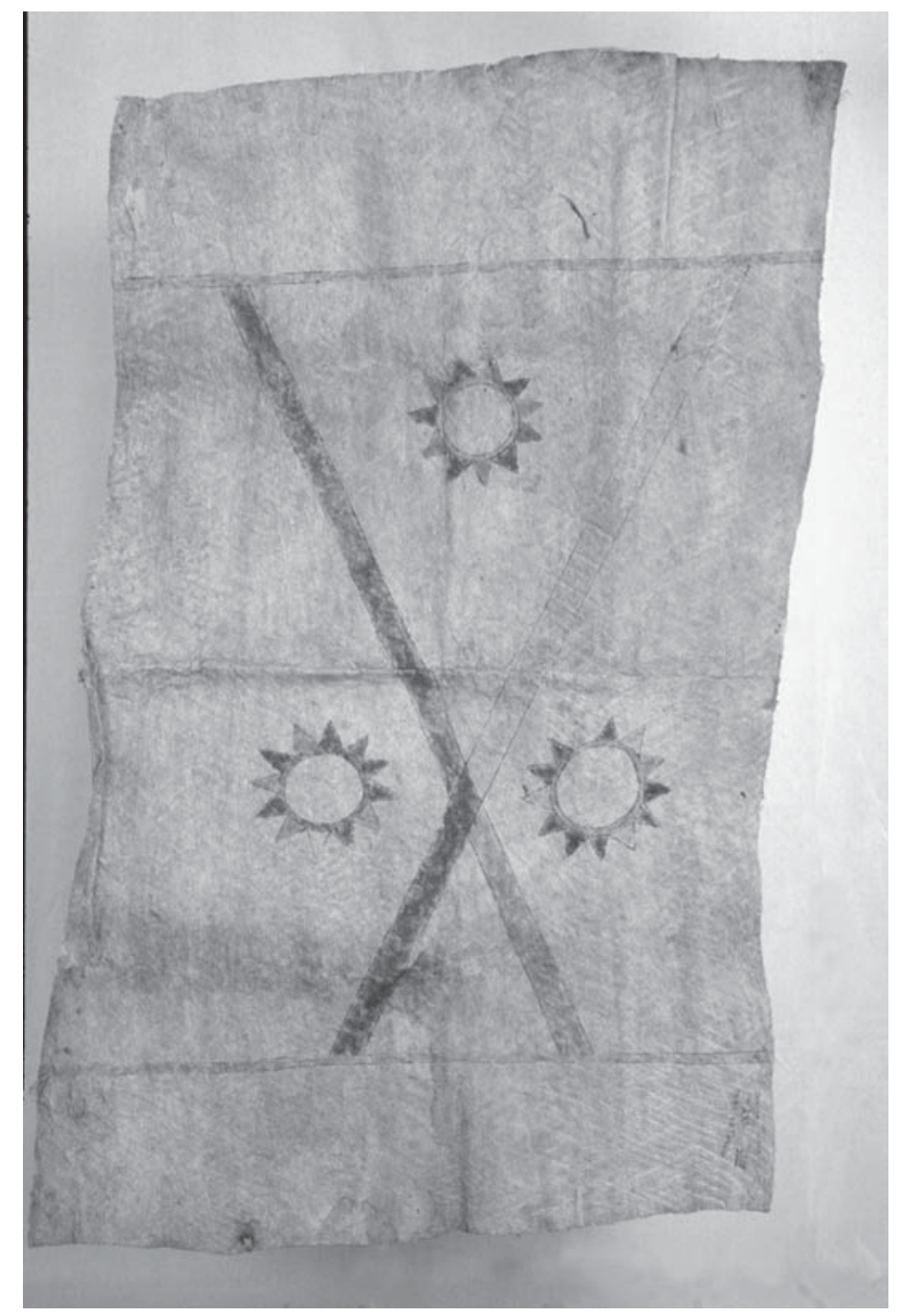

Pano 4268 
Como castigo para a vergonha social causada pelo incesto, as divindades isolaram os irmãos no mundo de cima, onde devem permanecer vigiando para que as transgressōes não voltem a acontecer. Quando alguma das estrelas é considerada filho de seu pai (Lua), isto anuncia a entrada na puberdade de uma moça, ou seja, a menina torna-se Worecü, que significa "moça de Lua" (Camacho, 2003, p. 8), uma vez que evoca o incesto primordial e a idéia de que todos devem reverenciá-la e respeitá-la.

Em uma versão da canção de Lua (Tawemacu tchiga) registrada no Enepü, relata-se que descobriram o irmão incestuoso no momento em que a moça, orientada por sua avó, jogou sumo de jenipapo no rosto de Lua. Em diferentes versōes da narrativa do incesto entre Lua e a moça Wocha (Camacho, 2003, p. 9), esta última ora aparece como sua cunhada (relato no Enepü, Terra Indígena Évare II, Brasil) ora como sua irmã (relatos de habitantes de Campo Alegre, Terra Indígena Évare I, Brasil; e de Nazaré, Departamento do Amazonas, Colômbia). Em outra versão, o primeiro incesto foi entre Lua e sua irmã Sol. A seguir um resumo do relato:

Uma moça estava grávida e não sabiam quem era o pai. Sua avó orientou-lhe para descobrir quem era o pai:

- Hoje você vai lá e tira o sumo de jenipapo e coloca do lado da sua rede. De noite, quando ele vier, você mela na sua mão e faz de conta que vai agradá-lo. Pega no rosto dele e basta só isso para descobrir quem é essa pessoa. Assim fez a moça, quando Lua deitou-se com ela. No outro dia, amanheceu. Lua, que naquele tempo era terrestre, sentiu o que era o jenipapo. Correu para o mato para tentar limpar o rosto. Tentou com todas as folhas brancas que existem no mato: limpava o jenipapo e jogava a folha. Aquelas folhas que ele jogava fora transformavam-se em pássaros pretos chamados Coró Cachimbo. Mesmo assim, aumentou o preto da pintura do jenipapo, e o rosto dele tornou-se cada vez mais escuro. Por isso ficou com vergonha, 
Priscila Faulhaber. “As estrelas eram terrenas”...

queria ir embora. Até que se transformou em Lua no céu. Hoje nós vemos no céu a cara de Lua, que tem aquela massa preta, por causa daquela pintura do jenipapo. (Pedro Inácio Pinheiro, Enepü, Brasil)

O pássaro preto, denominado regionalmente Coró Cachimbo, no qual se transformava a folha com que Lua queria limpar o seu rosto, representa uma junção de opostos: dia e noite, sol e chuva, luz e escuridão. Registra-se a proibição de falar o verdadeiro nome de Coró Cachimbo (Üakü) porque se não tudo ficará escuro, começará a chover, e a chuva transformar-se-á em temporal.

Esta narrativa sobre Sol e Lua integra-se a relatos cosmogônicos, como a narrativa de Wǘcutcha, cuja ascensão e declínio de constelações representam a chegada e o fim das chuvas:

No tempo passado, todas as estrelas que estão no céu eram terrenas. $\mathrm{O}$ grande problema naquele tempo é que essa Onça matava muita gente. A Onça-Jaguar era o gigante, o rei das onças. O Ngutapa, nosso pai eterno, conseguiu matar essa Onça. Esse osso que tem ele jogava e se transformava como um objeto vivo. Tirava o osso do lado da perna dele. Por isso chama Wǘcütcha, porque era usado como esse gancho. Assim como a gente dobra as pernas, fica esse gancho que são as pernas dessa Onça. Era a onça mais perigosa do mundo naquela época. Por isso chama osso do Wü̈ütcha: é um gancho para pendurar tudo que tem no mato. Como uma árvore ou madeira que fica torta ou como uma dobra de braço da gente. Como um tronco no qual se bateu muitas vezes seguidas. No tempo passado, quando alguém dormia, ia à casa da avó do Wǘcütcha, escutava o som de um grito dizendo:

— Daqui a pouco, se duvidarem, eu vou comer.

Assim era o som da zoada do ronco da avó do Wǘcütcha. Quem quisesse mandar essa pessoa embora, deveria levar um porrete de madeira. Onde encontrasse a árvore torta igual ao gancho, deveria perguntar: 
— Para onde ela está indo?

Os outros companheiros da Onça perguntavam para onde ia aquela pessoa. Aquele tronco ficou gritando:

— Não me aperreia porque eu não estou muito sadio, porque eu estou sentindo muita dor.

Não respondia para não alcançar quem quer que fugisse do Wücütcha. Houve, naquela época, uma menina que conseguiu escapar. (Francisca Arapasso, Enepü, Brasil)

A relação entre ascenção e ocaso das constelações Ticuna é exposta no relato que se segue:

As estrelas cabem nas suas respectivas constelações. Primeiro é Wǘcütcha. Depois do inverno, o verão começa a caminhar. É a Onça. Depois aparece Coyatchicüra no mês de maio, num início de noite, quando os jacarés aparecem na praia. Baweta aparece em setembro, mês da tartaruga. Em maio caem Wǘcütcha e Coyatchicüra. Todos fazem "ram, ram!". Caem todos juntos no fim de maio. Em julho vêm de novo. Baweta começa a aparecer já no mês de julho. Quando cai Wǘcütcha, a partir de maio, começam a aparecer jacaré, tartaruga. O ápice é setembro... No mês de maio caem as constelações junto com os seus planetas. É a época do verão. Em julho aparecem de novo para o próximo ano. Coya e Wü ü̈tcha saem do céu de maio a setembro. (Fernando Marques ou Ütchancu, comunidade Nazaré, traduzido por Luiz Angel)

Essas constelações relacionam-se com mitos referentes à ascensão e descida de diferentes animais. Wǘcütcha é uma fera celeste relacionada com o clã Onça, que matou a mãe grávida dos filhos de Lua, os quais, por sua vez, vingaram a morte da mãe matando a fera e lançando ao céu sua perna, pela qual ascendeu. Coyatchicüra é a "Queixada do Jacaré", 
Priscila Faulhaber. “As estrelas eram terrenas”...

que subiu ao céu depois que os sete meninos transportados por ele rebelaram-se e o mataram. Baweta (coletivo de tartaruga) é o casco no qual estão apinhados os sete meninos. Eram ovos de Jacaré, mas a avó deles o enganou, dizendo que eram de tartaruga, se não o Jacaré os teria devorado. O Tamanduá era a mais feroz das onças, e por este motivo Yoi castigou-o, afinando seu bico para que ele passasse a alimentar-se somente de formiga da terra. Mesmo assim, o Tamanduá enfrentou a Onça, e a luta destes dois animais é visível no céu durante os meses de estiagem. O "Caminho da Anta" é o caminho por onde circulam todos os animais que transpuseram as barreiras que separam a terra do céu. As constelações Ticuna permanecem todo o tempo no céu, mas se tornam visíveis apenas quando anunciam acontecimentos importantes, tais como o início das estações da chuva e da estiagem, ou os tempos de amadurecimento das frutas silvestres.

\subsection{Movimento das constelações Ticuna e sazonalidade}

O movimento das constelações Ticuna na cuia celeste - que coincide com a representação do céu na astronomia convencional - corresponde a uma interpretação da sazonalidade das chuvas. Não se almeja neste trabalho chegar a uma precisão matemática dos cálculos astrométricos, mas pensar como os Ticuna representam o movimento dos corpos celestes de acordo com a sazonalidade do calendário agrícola e extrativo. A observação das estrelas se dá, sobretudo, no início da noite, em um período entre $18 \mathrm{~h} 00$ e 20h00, mas também se registram eventos ocorridos ao final da noite e início do amanhecer. Há variações conforme o local onde o observador está situado, seja à beira do rio, seja em áreas mais elevadas, próximas às cabeceiras dos igarapés. As condições atmosféricas, como presença ou ausência de névoa ou de nuvens baixas, de- 
terminam a visão que eles podem ter de determinados astros nesses momentos de observação.

Segundo explicaram no Enepü, a influência da sazonalidade para as atividades de subsistência Ticuna é mais marcada na beira do Solimões, uma vez que nas cabeceiras dos igarapés, como no Enepü, existe fartura durante todo o ano. No Enepü, árvores como ingá e palmeiras como açaí são férteis durante todo o ano, porque a terra é "virgem" e enriquecida por adubos naturais. No lago Preto, localizado dentro dos limites do Enepü, os moradores se abastecem de peixe, que é abundante durante o ano inteiro. No Solimões, porém, há peixe somente de abril a julho, quando a água desce. A época de fartura de caça no Solimões é de abril a setembro. Quando esse rio está cheio, de novembro a março, as pescarias tornam-se mais difíceis. O fruto da palmeira do açaí nativo é colhido no verão. Costumam guardar esse fruto para prepará-lo no inverno, tempo de escassez de caça e pesca. Informam que, agindo conforme um planejamento e fazendo roça regularmente, durante todo o ano há coleta agrícola. A coleta das plantas cultivadas também ocorre durante a estiagem, como é o exemplo da pupunha, que leva três ou quatro meses para crescer e é colhida durante os meses de março e abril. O tempo de coleta de ingá é de abril a setembro. Existe uma certa flexibilidade na adaptação do calendário de atividades agrícolas e extrativas conforme o período de chuva, quando a pesca e a caça são mais escassas, e o período de seca, quando há maior abundância, porém quando também aumentam as dificuldades de navegação e transporte com a redução do volume de água dos igarapés, furos e canais que ligam os rios. A cultura tradicional não está preparada, porém, para as alterações imprevistas do período das chuvas. Como aconteceu em 2002, com a antecipação para julho do repiquete (subida das águas) - que ocorre normalmente em setembro - destruindo a agricultura de ciclo curto, causando escassez de pesca, alterando as bases da alimentação. 
Priscila Faulhaber. “As estrelas eram terrenas”...

Comparando-se as constelações Ticuna com as constelações convencionadas na astronomia ocidental, apresento, a seguir, quadro comparativo das constelaçôes Ticuna e as ocidentais, das posiçôes celestiais e das estaçôes correspondentes ${ }^{10}$.

\section{Quadro II: Correlações entre constelaçôes Ticuna e ocidentais}

\section{Constelações}

Coyatchicüra

(Queixada do Jacaré)

Wü̈cütcha

(Fera do clã Onça)

Baweta

(Coletivo de Tartaruga)

$\mathrm{Ai}$

(Onça)

Tchatü

(Tamanduá)

\section{Posição/Estação}

Norte Celestial

chuvas

Norte Celestial

chuvas

Norte Celestial

chuvas

Sul Celestial

chuvas

Sul Celestial

estiagem
Correlação

Híades

constelação do Touro

constelação de Órion

duas constelações:

Plêiades e Perseu

Escorpião

envolve quatro constelações:

Triângulo Austral,

Coroa Austral, Norma e Ara

A forma do desenho de Baweta (coletivo de tartaruga) associa-se ao conjunto de estrelas das constelaçôes convencionais das Plêiades e de Perseu, sendo seus olhos os pés de Perseu (Ômicron Persei e Atik). Supõe-se que a forma de $\mathrm{V}$, que para a astronomia ocidental está relacionada com as Híades, no vértice da cabeça do Touro, recebe pelos Ticuna o nome de Coyatchicüra (Queixada do Jacaré) ${ }^{11}$. Em um desenho Ticuna, a pata esquerda do Jacaré corresponde à estrela Euratis, e a pata traseira direita a $\varepsilon$ (epsílon), $\eta$ (eta) e $\zeta$ (zeta). A cauda está em o (ômicrom) e $\zeta$ (zeta), de Perseu. 


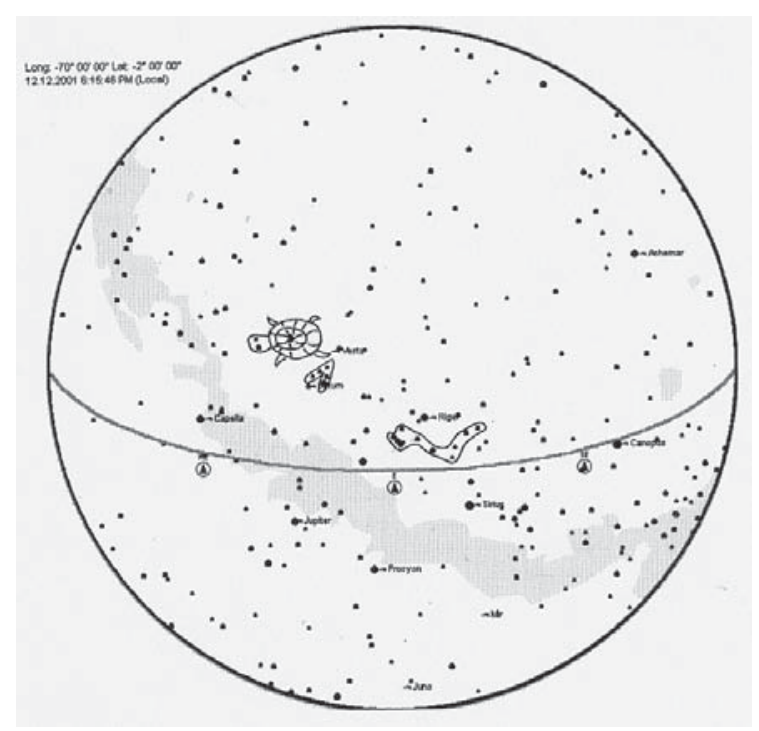

Carta 1

Ascensão de Baweta, Coyatchicüra e Wücütcha (início da estação das chuvas). Latitude $\left(-2^{\circ}\right)$, longitude $\left(-70^{\circ}\right)$, data $(12 / 12 / 2001)$, hora (18h15min). (Fonte: Software Starry Night. Desenho: Pedro Inácio Pinheiro)

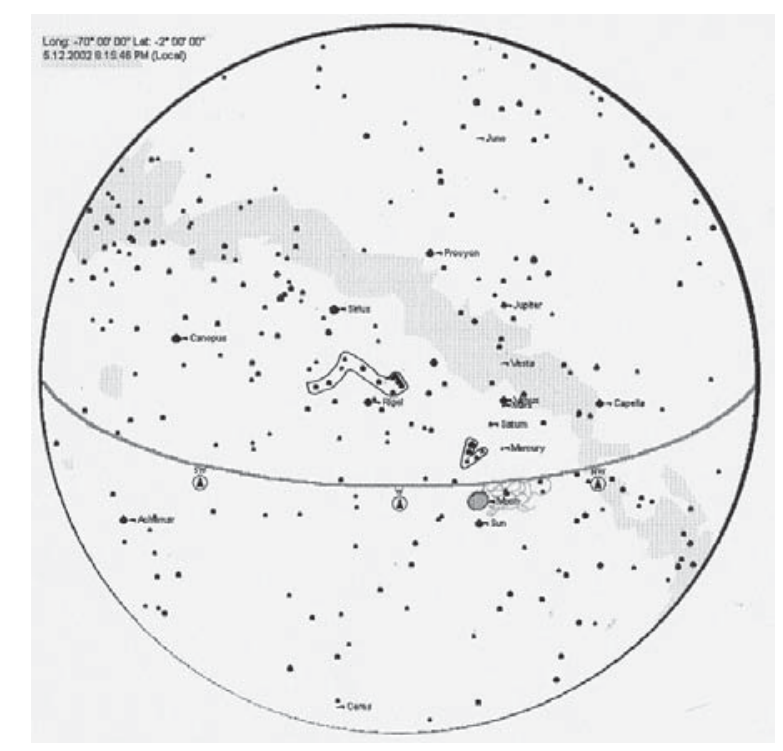

\section{Carta 2}

Descenso de Baweta, Coyatchicüra e Wǘcütcha.

Data (12/5/2002), hora (18h $15 \mathrm{~min})$.

(Fonte: Software Starry Night. Desenho: Pedro Inácio Pinheiro) 
Priscila Faulhaber. “As estrelas eram terrenas”...

A perna de Wǘcütcha é relacionada com as estrelas que, na astronomia convencional, são agrupadas com o nome de Órion. Os dedos dos pés estariam nas Três Marias, e a quebra da perna em $\alpha$ (alfa), $\gamma$ (gama), $\beta$ (beta ), $\varepsilon$ (epsílon).

O início das chuvas é anunciado pela ascenção de Baweta, que aparece no céu no início da noite, a Leste, no fim de novembro. Após subir Baweta, sobe a "Queixada do Jacaré". A perna de Wü̈ü̈tcha corresponde a Órion. Ela começa a desaparecer no céu, a Oeste, a partir de 20 de maio ao anoitecer.

No decorrer do verão, ocorre a luta entre o Tamanduá (Tchatü) e a Onça (Ai), cujo fim corresponde à morte e ascensão de Wǘcütcha. Os olhos do Tamanduá estariam em $\beta$ do Triângulo Austral, sua cauda na constelação da Coroa Austral e seu corpo nas constelações de Norma e Ara. A pata direita da Onça estaria em $\alpha$ (Antares), $\sigma$ (sigma) e $\tau$ (tau) no Escorpião; os olhos estariam em $\varepsilon$ e $\mu$, também do Escorpião; e a pata esquerda em $\gamma$ (Shaula), $v$ (nu), $\imath$ (iota) e $\theta$ (teta) da mesma constelação. Afirmaram que essa luta foi o desfecho da aventura incestuosa entre Lua e sua irmã, seguida do assassinato da mulher grávida. Os parentes da vítima mataram a fera associada ao clã Onça, para impedir o eclipse lunar. A saída do céu de Tchatü, a Oeste, ao anoitecer em fins de novembro, corresponde ao aparecimento da perna de Wü̈ütcha a Leste à mesma hora, representando o início das chuvas.

A identificação dos olhos da onça deve-se a Curt Nimuendaju (1952, p. 143). A identificação das constelações Ticuna aqui apresentadas realizou-se com base nesse registro inicial. Os atuais registros etnográficos confirmam o registro etnológico de que, no início da briga, a Onça encontrava-se em cima do Tamanduá, ao passo que, ao fim, o Tamanduá encontra-se sobre a Onça. 
Revista de Antropologia, São Paulo, USP, 2004, v. 47 № 2.

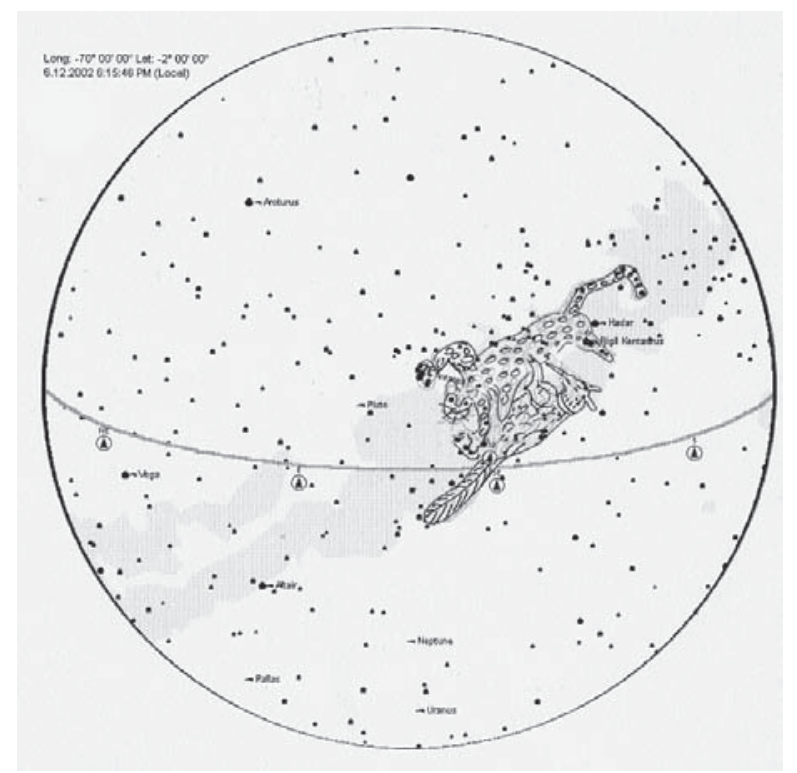

Carta 3

Ascensão da briga da Onça e do Tamanduá.

Data (12/6/2002), hora (18h15min).

(Fonte: Software Starry Night. Desenho: Pedro Inácio Pinheiro)

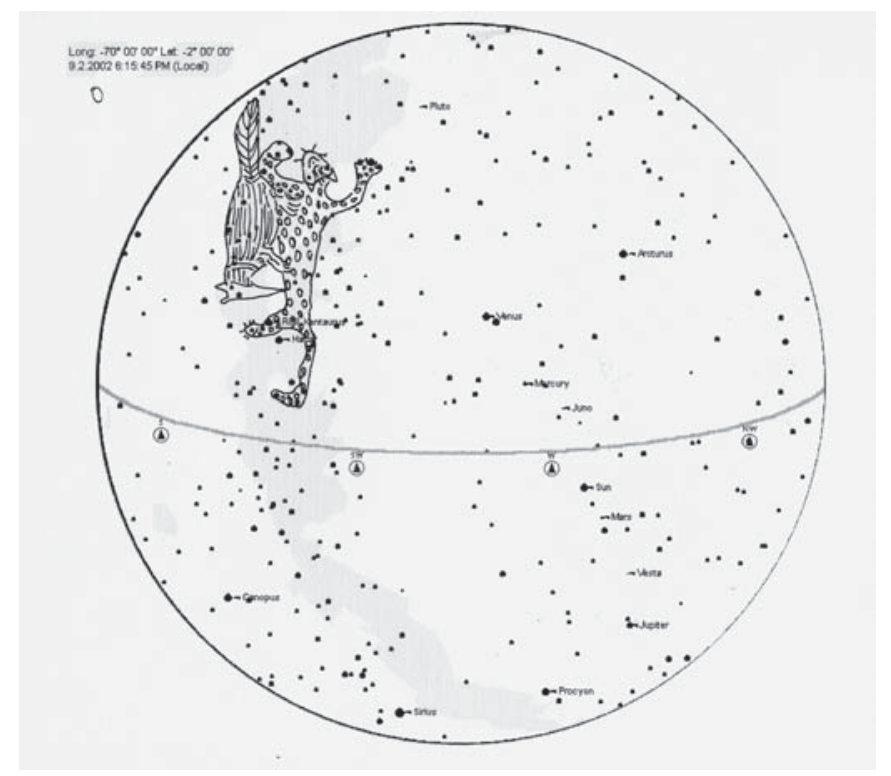

\section{Carta 4}

Briga da Onça e do Tamanduá no alto do céu. Data (2/9/2002), hora (18h15min).

(Fonte: Software Starry Night. Desenho: Pedro Inácio Pinheiro) 


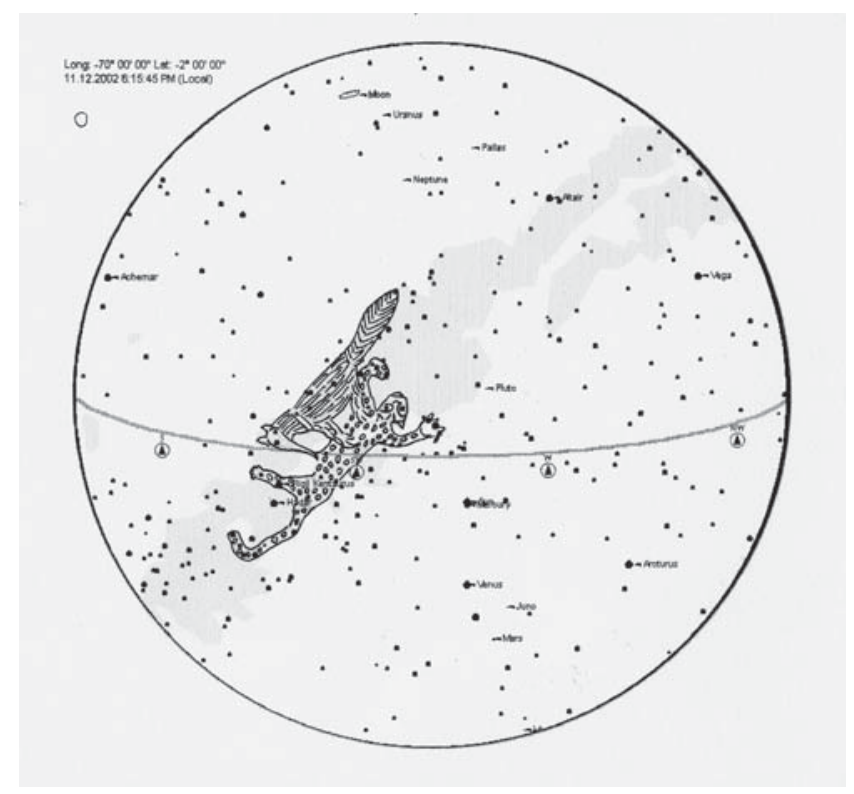

\section{Carta 5}

Ocaso da briga da Onça e do Tamanduá.

Data (12/11/2002), hora (18h15min).

(Fonte: Software Starry Night. Desenho: Pedro Inácio Pinheiro)

\section{Considerações finais}

Os desenhos dos Ticuna de hoje podem ser correlacionados com a iconografia dos artefatos rituais Ticuna armazenados em museus. Esses desenhos reconstituem os ícones de seu passado recente, revivido nas recordaçōes dos mais velhos sobre as imagens vivenciadas no curso de sua vida. Como se se tratasse da trajetória de uma caçada, na qual o caçador identifica as pistas deixadas pelos animais, seguindo suas pegadas até conseguir cercá-los, desvendar suas artimanhas (Ginzburg, 1999, p. 131). As narrativas gráficas são uma forma de recriar essas peripécias, deixando ao mesmo tempo um rastro para reflexão dos que vêm depois. 
Constituem, portanto, uma forma de conhecimento que serve para pensar as circunstâncias presentes, bem como decifrar aspectos de seu passado. Como forma de conhecimento, servem igualmente para pensar as transformaçōes ambientais de maneira geral e as alterações climáticas de modo específico, também impressas na iconografia dos artefatos rituais Ticuna. O que interessa mostrar, do ponto de vista antropológico, não é tanto se os prognósticos indígenas têm ou não um fundo de verdade, mas como as preocupações dos Ticuna diante de fenômenos meteorológicos constituem um modo de pensar, dentro de uma lógica própria, a possibilidade de controle humano sobre as transformações ambientais. Não existe uma coincidência direta entre suas concepções sobre os corpos celestes e as nossas, uma vez que se baseiam em diferentes concepções do Universo, ainda que tanto para eles como para nós a contemplação do céu possa significar uma representação da passagem do tempo.

O relato Ticuna sobre o incesto primordial mostra, de modo impressionante, que o gênero feminino é importante para a especificidade cultural deste povo. A festa da puberdade feminina Ticuna consiste em um rito que expressa inquietações em face do sucesso na caça, na pesca e na agricultura, associado a estratégias de armazenamento alimentar conforme as oscilações climáticas e o movimento, sazonal, das enchentes e vazantes. Trata-se, portanto, de um culto à fertilidade não apenas da moça como da natureza em que ela vive com seu grupo de consangüíneos e afins. Constitui-se, também, em um rito identitário - o qual não expressa necessariamente a coesão social, uma vez que também implica o extravasamento de tensões - que envolve a postura do grupo em relação tanto ao manejo de recursos quanto da transmissão de cultura e de mecanismos de socialização de geração a geração.

A entrada das máscaras em momentos determinados desse ritual implica a dramatização - em termos da representação de enunciados míticos dentro do contexto social - de um jogo de sombras no qual se viven- 
Priscila Faulhaber. “As estrelas eram terrenas”...

cia a relação com o desconhecido, ou seja, com os seres invisíveis que regem a vida da floresta e com os desafios da vida societária. Coloca-se em jogo não apenas a sobrevivência da moça, mas a sobrevivência de todo o seu grupo de referência. Realizam o ritual não apenas para a moça, mas para aqueles com quem ela convive considerarem-se protegidos.

A dramatização da chegada da chuva, da ventania, do vendaval, da tempestade e, ao final, do arco-íris e da bonança expressa as expectativas em relação à meteorologia e às mudanças climáticas e ambientais. Para compreendê-las e conseguir alguma segurança de previsibilidade, os antigos observavam o movimento da Lua, do Sol e das estrelas. Esse conhecimento vem sendo transmitido por meio dos relatos míticos. A presença de imagens relacionadas com corpos celestes, na quase totalidade da iconografia inscrita nos artefatos rituais da coleção Ticuna de Curt Nimuendaju, é uma evidência de que nesta iconografia a cosmovisão e os rituais deste povo encontram-se relacionados e expressam uma forma de pensar problemas práticos que se colocam em seu cotidiano.

\section{Notas}

1 A pesquisa de campo para este trabalho foi realizada entre 1997 e 2003, nas Terras Indígenas Évare II (comunidades Enepü, Otaware, Ribeiro ), Évare I (comunidades Cajari II e Barro Vermelho) e nos resguardos colombianos de Arara e Nazaré. Agradeço a Fernando Vieira, pelas orientações para identificação do céu, a Hugo Camacho, pela visão de conjunto da etnografia Ticuna, a Pedro Inácio Pinheiro, que me conduziu aos lugares de identidade Magüta, e a Robin Wright, pelas correções no abstract.

2 Adota-se aqui, para os termos em língua Ticuna referidos à mitologia deste povo, a grafia convencionada nos trabalhos da lingüista Marília Faró Soares, do Departamento de Antropologia, que assessorou o projeto do qual este artigo é um produto. 
3 As indumentárias de dança foram esboçadas pela estudante de antropologia Luiza Mastop-Lima (1998-2000) e redesenhadas pela estudante de arquitetura Tília Monte (2000-2002), que desenhou os instrumentos. O inventário das peças foi estabelecido com a colaboração das estudantes de antropologia Rita de Cássia Domigues-Lopes (1998-2000) e Ainete Rocha-Guedes (2000-2002). As fotos são da autoria de Miguel Chikaoka.

4 Em novembro de 1999, em pesquisa em Letícia, na Colômbia, tive oportunidade de escutar os comentários sobre as fotos e os croquis das máscaras da referida coleção, por anciãos Ticuna assistidos por dois especialistas Ticuna treinados em lingüística e pelo antropólogo Hugo Camacho, que confirmaram minhas suposições sobre a intrínseca relação entre o pensamento mítico, as performances rituais e as representaçóes sobre o meio ambiente. Em novembro e dezembro de 2000, em nova pesquisa de campo, após participar em uma festa de puberdade, coletei 15 artefatos rituais Ticuna (três caras, uma máscara inteiriça, vestimentas de líber, um escudo). Em 2002, retornei ao alto Solimões em abril-maio e julho-agosto, trabalhando nas comunidades Nazaré, da Colômbia, Barro Vermelho e Enepü, no Brasil, quando coletei três artefatos rituais (duas caras e uma vestimenta de máscara).

5 De acordo com Goulard (2002), é o xamã que traz às costas essa roda, que serve como um escudo.

6 Repiquete é uma cheia intermediária que ocorre antes do período da chuva, geralmente no mês de setembro.

7 O repiquete foi associado, pelos Ticuna do resguardo colombiano de Nazaré, ao efeito estufa, que provocou o degelo dos Andes e aumentou o volume do rio Marañon, no Peru, e Amazonas, na Colômbia (continuação do Solimões, nome que recebe no Brasil).

8 A festa da moça Boatana foi realizada no ano 2000, nessa mesma situação, com Júpiter e Saturno em Touro.

9 No inventário lexical, elaborado por Marília Facó Soares para o CD-ROM Magüta Aru Inü. Jogo de memória. Pensamento Magüta (Faulhaber, 2003), o termo Yacürana significa cigarra venenosa que vive nas árvores, por exemplo, na árvore de copaíba. É branca com manchas negras. Se uma pessoa for mordida por uma yacürana, ela só se salvará se tiver relações sexuais com uma pessoa do sexo contrário.

10 Allan Feitosa, do Planetários Amazônia, plotou as cartas nas quais os Ticuna, Pedro Inácio Pinheiro e Luís Angel Ramos, desenharam simulacros das constelações 
Ticuna. Os cálculos estabeleceram-se com base na latitude $2^{\circ}$ e longitude $70^{\circ}$, com o apoio de Oswaldo dos Santos Barros, do Planetário do Pará. Fernando Vieira, do Planetário da Cidade do Rio de Janeiro, realizou a correspondência entre os traços dos animais míticos Ticuna e as estrelas convencionadas pela astronomia ocidental, bem como a revisão final deste texto no que se refere à identificação do céu. $O$ quadro II foi elaborado com a colaboração de Ivânia Neves Corrêa (2004). Ao final, Flávia Pedroza retificou as reflexôes astronômicas.

11 Registram-se entre os Ticuna versões que associam a mesma figura de Coyatchicüra às estrelas do rabo da constelação convencional do Escorpião. Optou-se por não incluir essas representaçôes nas presentes inferências por decisão dos Ticuna - provavelmente por dúvidas em apresentar simultaneamente as duas Coyatchicüra no céu, uma vez que se trata da mesma entidade -, que estiveram presentes na sessão de cúpula em Belém, durante as atividades de conclusão deste trabalho, entre 26 de novembro e 15 de dezembro de 2002.

\section{Bibliografia}

ALVIANO, Fr. F.

1943 "Notas etnográficas sobre os Ticunas do Alto Solimões", Revista Instituto Histórico e Geográfico Brasileiro, Rio de Janeiro, vol. 180-181: 6-33.

BARABAS, A.

"Movimientos étnico-religiosos y seculares em América Latina", Am. Indig., México, vol. 46(3): 495-529.

1989 Utopias indias. Movimientos sociorreligiosos em México, México, Enlace/Grijaldo.

BLOCH, E.

1979 El principio esperança, Madri, Aguilar.

CAMACHO, $\mathrm{H}$.

1995 Magüta, la gente pescada por Yoi, Bogotá, Colcoltura.

$1996 \quad$ Nuestras caras de fiesta, Bogotá, Colcoltura.

$2000 \quad$ Historias de los Abuelos de Muruap, Bogotá, Imprenta National de Colombia.

2003 "Rito y cosmogonia entre los Tikuna del Trapecio Amazónico", Letícia, préprint, $21 \mathrm{pp}$. 
CARDOSO DE OLIVEIRA, R.

1970 “Totemismo Tukúna?”, in (org.), Mito e linguagem social. Ensaios de antropologia social, Rio de Janeiro, Tempo Brasileiro.

1972

$O$ indio e o mundo dos brancos, São Paulo, Pioneira.

CHAUMEIL, J.-P.

2000 Voir, savoir, pouvoir. Le chamanisme chez les Yagua de L'Amazone péruvienne, Genève, Georg Editeur.

CIPOLLETTI, M. S.

1991-1992 "La creación del cosmos y sus protagonistas: los Secoya (Tucano) de la Amazonía ecuatoriana", Scweizerische Amerikanisten-Gesellschaft, Bull. 55-56, p. 11-21.

DELERUE, Alberto

2001 Rumo às Estrelas. Guia prático de observação do Céu, Rio de Janeiro, Zahar.

FAULHABER, P.

1994 “Uma viagem ao 'mundo de lá. Imaginário e movimento dos índios no JapuráSolimões", in BARABAS, A. (org.), Religiosidade y resistencia indígenas hacia el fin del milênio, Quito, Abya-Yala, p.157-88.

1999 "A festa de To'oena. Relatos, performance e etnografia Ticuna", in OLIVERIA FILHO, J. P., Amazônia em cadernos. Os Ticunas hoje, Manaus, Ufam, p. 105-20.

2001 "A fronteira na antropologia social: as diferentes faces de um problema", Revista Brasileira de Informação Bibliográfica em Ciências Sociais, São Paulo, Anpocs, p. 105-26.

2002 "The Mask Designs of the Ticuna Curt Nimuendaju Collection", in MYERS, T. \& CIPOLlETTI, M. S (org.), BAS. Bonner Americanistsche Studien 36, Bonn, Bonn Universtität, p. 27-46.

FAULHABER, P. (org.)

2003 Magüta Arü Inü. Jogo de memória. Pensamento magüta, Prêmio Rodrigo de Melo Franco de Andrade, Iphan, Belém, Museu Goeldi.

GINZBURG, C.

1999 Mitos, emblemas e sinais. Morfologia e história, São Paulo, Companhia das Letras. 
Priscila Faulhaber. “As estrelas eram terrenas”...

GOLOUBINOFF, M. et al.

1997 Antropologia del clima en el mundo hispanoamericano, Quito, Abya-Yala.

GOULARD, J.-P.

1998 "Les genres du corps. Conceptions de la personne chez les Ticuna de la Haute Amazonie”, Paris, École des Hautes Études en Sciences Sociales.

2002 "Un objeto ritual: el chine o escudo de baile de los Ticuna, in MYERS, T. \& CIPOLLETTI, M. S (org.), BAS. Bonner Americanistsche Studien 36, Bonn, Bonn Universtität, p. 47-62.

HUGH-JONES, S.

1979 The Palm and the Pleyades. Initiation and cosmology in Nortwest Amazon, Cambridge, Cambridge Univesity.

LÉVI-STRAUSS, C.

1962 O pensamento selvagem, São Paulo, Companhia Editora Nacional.

1991 O cru e o cozido. Mitológicas, São Paulo, Brasiliense.

MOURÃO, R. R. de F.

$1995 \quad$ Carta celeste do Brasil, Rio de Janeiro, Bertrand Brasil.

NEVES CORRÊA, I.

2004 Interseções de saberes nos Céus Surui, dissertação de mestrado, Departamento de Ciências Sociais, UFPA, 128 pp.

NIMUENDAJU, K.

1952 The Tukuna, Berkeley/Los Angeles, University of California.

1959 "The Tukuna", Handbook of South American Indians, vol. 3: 713-25.

OLIVEIRA FILHO, J. P.

1988 O nosso governo: os Ticuna e o regime tutelar, Rio de Janeiro, Marco Zero/MCT/ CNPq.

1999 Ensaios de antropologia histórica, Rio de Janeiro, UFRJ. 
Revista de Antropologia, São Paulo, USP, 2004, v. 47 № 2.

RIVIÈRE, G.

1997

"Tiempo, poder y sociedad en las comunidades Aymaras del Altiplano (Bolívia)", in GOLOUBINOFF et al. (org.), Antropologia del clima en el mundo hispano americano, Quito, Abya-Yala, 1997, tomo II: 31-54.

TAMBIAH, S. J.

1985 "A performative approach to ritual", Culture, thought and Social Action, Cambridge, Harvard University, p 123-66.

TURNER, V.

1982 From ritual to theatre. The human seriousness of play, New York, Paj Publications.

SULLIVAN, L. E.

1988 Icanchu's Drum. An Orientation to Meaning in South American Religions, New York/London, Macmillan Publishers.

VIEIRA, F.

1999 Identificação do céu, Rio de Janeiro, Fundação Planetário da Cidade.

WILBERT, J.

1996 Mindfull of famine. Religious climatology of the Warao indians, Cambridge, Harvard University. 
ABSTRACT: The anthropology of weather includes the study of the significance of astronomical and atmospheric phenomena within indigenous myths and rituals as well as of the importance of representations of these phenomena for the social practices of indigenous people. Among the Ticuna of Upper Solimões (Brazil) the celestial bodies depicted in the iconography of artifacts used in the Ticuna puberty festival can be related to some aspects of this people's mythology and cosmovision, as expressed in ritual chants and speeches. This relation is translated into expectations regarding the inter-relationships between the annual movement of the stars in the sky and the influence of the rainy and dry seasons for survival activities. The identification of groups of celestial bodies visualized by the Ticuna allows us to establish their correlations with the conventionally reconized constellations.

KEY-WORDS: anthropology of weather, seasonality, star movements, sky identification. 